National Marine

Fisheries Service

NOAA
Fishery Bulletin

ar established in 1881 o
Spencer F. Baird

First U.S. Commissioner of Fisheries and founder of Fishery Bulletin
Abstract-The commercially valuable Atlantic surfclam (Spisula solidissima) is harvested along the northeastern continental shelf of the United States. Its range has contracted and shifted north, driven by warmer bottom water temperatures. Declining landings per unit of effort (LPUE) in the Mid-Atlantic Bight (MAB) is one result. Declining stock abundance and LPUE suggest that overfishing may be occurring off New Jersey. A management strategy evaluation (MSE) for the Atlantic surfclam is implemented to evaluate rotating closures to enhance Atlantic surfclam productivity and increase fishery viability in the MAB. Active agents of the MSE model are individual fishing vessels with performance and quota constraints influenced by captains' behavior over a spatially varying population. Management alternatives include 2 rules regarding closure locations and 3 rules regarding closure durations. Simulations showed that stock biomass increased, up to $17 \%$, under most alternative strategies in relation to estimated stock biomass under present-day management, and LPUE increased under most alternative strategies, by up to $21 \%$. When incidental mortality caused by the fishery increased, the benefits seen under the alternative management were enhanced. These outcomes suggest that area management involving rotating closures could be valuable in insulating the stock and the commercial fishery from further declines as a northerly shift in range proceeds.

Manuscript submitted 28 June 2016. Manuscript accepted 27 March 2017. Fish. Bull. 115:300-325 (2017).

Online publication date: 4 May 2017. doi: 10.7755/FB.115.3.3

The views and opinions expressed or implied in this article are those of the author (or authors) and do not necessarily reflect the position of the National Marine Fisheries Service, NOAA.

\title{
Management strategy evaluation for the Atlantic surfclam (Spisula solidissima) using a spatially explicit, vessel-based fisheries model
}

\author{
Kelsey M. Kuykendall (contact author) ${ }^{1}$ \\ Eric N. Powell ${ }^{1}$ \\ John M. Klinck2 \\ Paula T. Moreno ${ }^{1}$ \\ Robert T. Leaf ${ }^{1}$ \\ Email address for contact author: kelsey.kuykendall@usm.edu \\ 1 Gulf Coast Research Laboratory \\ The University of Southern Mississippi \\ 703 East Beach Drive \\ Ocean Springs, Mississippi 39564 \\ 2 Center for Coastal Physical Oceanography \\ Department of Ocean, Earth, and Atmospheric Sciences \\ 4111 Monarch Way, 3rd Floor \\ Old Dominion University \\ Norfolk, Virginia 23529
}

The Atlantic surfclam (Spisula solidissima) is an economically valuable bivalve common to the sandy bottoms off the northeastern coast of the United States and Canada (Weinberg, 2005). The range of the Atlantic surfclam before recent effects of global warming spanned the western North Atlantic Ocean continental shelf from Nova Scotia to northern South Carolina, at depths of $10 \mathrm{~m}$ to $50 \mathrm{~m}$, and temperature determines the range boundaries (Goldberg and Walker, 1990; Weinberg, 1998; Jacobson and Weinberg$^{1}$; NEFSC ${ }^{2}$ ). They are gener-

1 Jacobson, L., and J. Weinberg. 2006. Atlantic surfclam (Spisula solidissima). In Status of fishery resources of the Northeastern US (R. Mayo, F. Serchuk, and E. Holmes, eds.), 1-8 p. Northeast Fish. Sci. Cent., Woods Hole, MA. [Available from website.]

2 NEFSC (Northeast Fisheries Science Center). 2013. 56 $6^{\text {th }}$ Northeast Regional Stock Assessment Workshop (56 ${ }^{\text {th }}$ SAW) assessment summary report. U.S. Dep. Commer, Northeast Fish. Sci. Cent. Ref. Doc. 13-04, 42 p. [Available from website.] ally not found where average bottom temperatures exceed $25^{\circ} \mathrm{C}$ (Cargnelli et al., 1999). Atlantic surfclams are relatively sessile planktivorous filter feeders that rarely vacate their burrow unless resuspended by storms or they are escaping predators (Ropes and Merrill, 1973; Prior et al., 1979), after which they rapidly reburrow into the substrate (Weinberg, 2005). The life span of Atlantic surfclam is approximately 30 years and has a maximum-recorded shell length (SL) of $226 \mathrm{~mm}$ (Fay et al. ${ }^{3}$; Cargnelli et al., 1999; Munroe et al., 2016).

The range of Atlantic surfclam has been shifting north and offshore since approximately 1970, driven primarily by warming bottom water temperatures (Cargnelli et al., 1999;

\footnotetext{
${ }^{3}$ Fay, C. W., R. J. Neves, and G. B. Pardue. 1983. Species profiles: life histories and environmental requirements of coastal fishes and invertebrates (midAtlantic) surf clam. U.S. Fish. Wildl. Serv., FWS/OBS-82/11.13, U.S. Army Corps Eng., TR EL-82-4, 23 p.
} 
Weinberg, 2005; Munroe et al., 2013; Hofmann et al., in press). Early evidence of this trend is the disappearance of Atlantic surfclams in Virginia and Maryland state waters between the 1970s and the 1990s (Loesch and Ropes, 1977; Powell4; Hofmann et al., in press) and the shift of the southern fishery from the Delmarva Peninsula to ports north (Powell et al., 2015). From the 1997 to 1999 period, the Atlantic surfclam population was considered to be near carrying capacity $\left(\mathrm{NEFSC}^{2}\right)$. Abundances were once high on the continental shelf off the Delmarva Peninsula, but declines in growth, maximum size, and tissue weight (Weinberg, 1998, 1999) were accompanied by increased mortality in this region (Weinberg, 2005; Weinberg et al. ${ }^{5}$ ). Separate fisheriesindependent surveys conducted in 2002 by the Northeast Fisheries Science Center of the National Marine Fisheries Service (NMFS) and the New Jersey Department of Environmental Protection revealed that a large mortality event had occurred sometime after 1999 that extirpated Atlantic surfclams from the southern inshore region off Delmarva Peninsula, followed by stock declines in both state and inshore federal waters off New Jersey (Powell4; Kim and Powell, 2004). An additional survey conducted in 2004 (Weinberg et al. ${ }^{5}$ ) confirmed the northward and offshore shift in the Atlantic surfclam stock.

One result of these mortality events was the redistribution of the stock north: namely an increasing abundance off the coast of Long Island, New York; the expansion of the population on Georges Bank; and the movement of the seaward boundary of the southern portion of the stock offshore in response to increased bottom water temperatures (Weinberg, 2005; Munroe et al., 2013; $\mathrm{NEFSC}^{2}$ ). Simulations by Narváez et al. (2015) based on stock assessment data from the Northeast Fisheries Science Center and bottom temperature time series obtained through implementation of the Regional Ocean Modeling System for the northwestern Atlantic indicated that episodic warm years caused elevated mortality events in older and larger clams and that these events have occurred with increasing frequency over the last several decades of the $20^{\text {th }}$ century. In the simulation study, Narváez et al. (2015) found that thermal stress decreased the Atlantic surfclam stock by $2-9 \%$ on the shelf regions that coincide with a majority of the regions used by the commercial fishery.

The Atlantic surfclam reaches marketable sizes of 120 to $150 \mathrm{~mm}$ SL within 6-7 years depending upon food availability and water temperature (Weinberg, 1998; Cargnelli et al., 1999; Weinberg et al., 2002; NEFSC $^{2}$ ). Growth rates within the first 3 to 5 years

\footnotetext{
${ }^{4}$ Powell, E. N. 2003. Maryland inshore surf clam, Spisula solidissima, survey August 2003 cruise report. Final report to J. H. Miles \& Co. Inc., 19 p. Haskin Shellfish Research Laboratory, Port Norris, NJ.

5 Weinberg, J. R., E. N. Powell, C. Pickett, V. A. Nordahl Jr, and L. D. Jacobson. 2005. Results from the 2004 cooperative survey of Atlantic surfclams. U.S. Dep. Commer., Northeast Fish. Sci. Cent. Ref. Doc. 05-01, 41 p. [Available from website.]
}

have been reported to be similar across much of the range of the Atlantic surfclam before the 1999 mortality event (Cargnelli et al., 1999). Increased bottom water temperatures above approximately $20^{\circ} \mathrm{C}$ negatively affect Atlantic surfclam nutrition by reducing ingestion rate and leading to a reduction in growth rate, condition, and maximum size (Marzec et al., 2010; Munroe et al., 2013; Munroe et al., 2016). Munroe et al. (2016) found that the maximum size had, in fact, declined for much of the stock since 1980. Simulation modeling of Atlantic surfclam population dynamics shows that this outcome can be derived solely from rising bottom water temperatures (Munroe et al., 2013, 2016), although a change in food supply would result in the same outcome.

Along the Mid-Atlantic coast, the Atlantic surfclam has supported a fishery since the 1960s that reached total revenues of $\$ 29$ million in 2011 (Weinberg, 1999; Weinberg et al. ${ }^{5}$; $\mathrm{NEFSC}^{2}$ ). The average rate of fishinginduced mortality (commonly termed "fishing mortality") in the stock south of Hudson Canyon has been higher than the fishing mortality rate over the whole stock and of the northern region since 2002; however, the fishing mortality rate, which historically has been less than $25 \%$ of the natural mortality rate $(\mathrm{M}=0.15 /$ year $)$, remains below the natural mortality rate $\left(\mathrm{NEFSC}^{2}\right)$.

For the last 30 years, most of the commercial landings within the U.S. Exclusive Economic Zone have been harvested along the coast of New Jersey and the Delmarva Peninsula (Weinberg, 1999; NEFSC $^{2}$ ). Landings in this region within the last decade have declined coincident with the latest phase of contraction in the distribution range of this species. According to the latest stock assessment, the Atlantic surfclam is not overfished, and overfishing is unlikely to occur in the next 5-7 years (NEFSC ${ }^{2}$ ). However, declining stock abundance has led to the termination of a once thriving clam fishery in the most southerly portions of its range since 2000. A decline in landings per unit of effort (LPUEs), coupled with rising fishing morality rates, has generated concern for the sustainability of the stock off New Jersey (Powell4; Weinberg et al.5; $\mathrm{NEFSC}^{2}$ ). The reopening of Georges Bank for harvesting of clams in 2010 (NOAA, 2012) -an area that was closed in 1990 owing to the risk of harvesting clams contaminated with paralytic shellfish poison (Jacobson and Weinberg ${ }^{1}$ ) - allowed some relief from fishing pressure in other regions, but landings over much of the remainder of the stock continue to produce the steady decline observed since 2008 (Fig. 1) (NEFSC ${ }^{2}$ ).

Declining abundance and LPUE south of Hudson Canyon have driven stakeholders' desire to enhance production in the New Jersey portion of the stock (Fig. 1), possibly through the implementation of area management, which has proven to be a useful tool for improving production in fisheries of sessile species (Powell et al., 2008; Cooley et al., 2015). Examples of fisheries where implementation of this strategy has been successful are the fisheries for sea scallop (Placopecten magellanicus) in the Mid-Atlantic Bight (MAB) and 


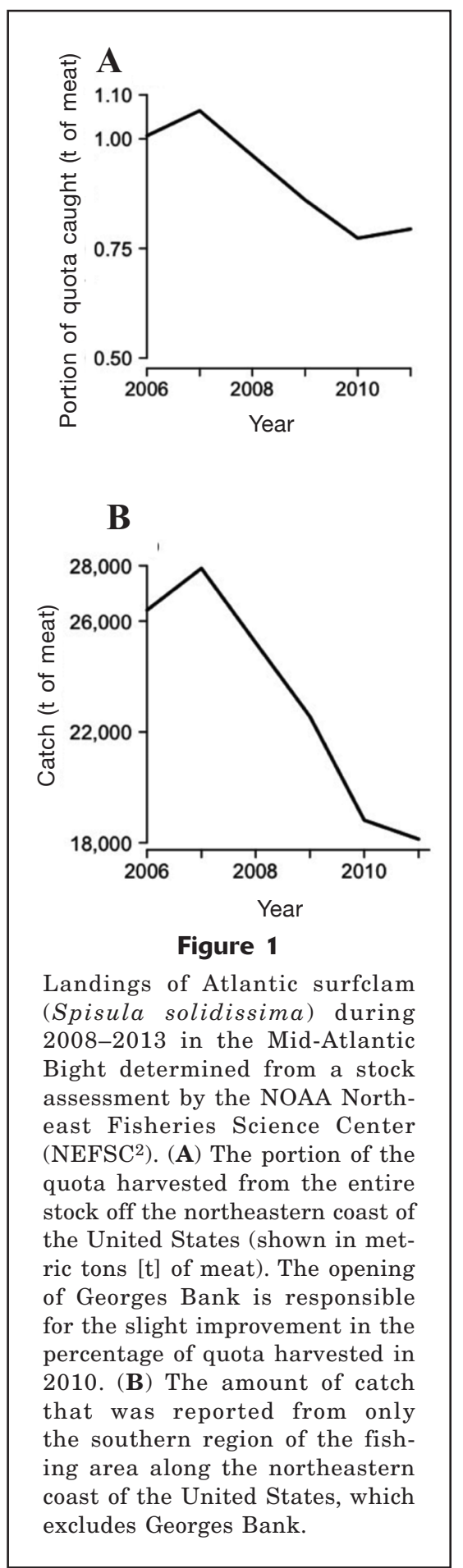

New England regions (Cooley et al., 2015), and the oyster fishery in Delaware Bay (Powell et al., 2008). One method for examining the risks and benefits associated with area management and management plans in general is to conduct a management strategy evaluation (Smith, 1994). An MSE is a quantitative tool used to evaluate a range of possible management procedures by comparing performance statistics or metrics (But- terworth and Punt, 1999; Martell et al.6; Punt et al., 2014). Butterworth et al. (1997) describe management procedures as "a set of rules which utilize prespecified data to provide recommendations for management actions." Performance metrics must be chosen carefully, preferably in collaboration with the stakeholders of the fishery, to ensure clear and easy interpretation of simulation results (Francis and Shotton, 1997). As examples, MSE has been used to contrast the performance of fishery alternative management strategies in the Pacific halibut (Hippoglossus stenolepis) (Martell et al. ${ }^{6}$ ), rock lobster (Jasus edwardsii) (Punt et al., 2013), and U.S. southeastern king mackerel (Scomberomorus cavalla) (Miller et al., 2010) fisheries (see Spillman et al., 2009; Baudron et al., 2010; Bastardie et al., 2010 for additional examples).

The objective of our study is to evaluate a range of area management options that may improve the Atlantic surfclam stock and the Atlantic surfclam fishery in the MAB. The Atlantic surfclam stock for this study is defined as the portion of the U.S. stock from approximately Shinnecock, New York, south to Chesapeake Bay. After specification of management options, the results of a series of simulations are presented and evaluated on the basis of performance metrics estimated with varying Atlantic surfclam population dynamics and a range of commercial procedures, including fishing behaviors. The inclusion of fishing behavior is critical because captains respond to new management measures, and this response will in part determine the degree of success of those management measures after implementation (Bockstael and Opaluch, 1983; Gillis et al., 1995; Mackinson et al., 1997; Dorn, 2001; Millischer and Gascuel, 2006). Subsequent statistical analyses of performance metrics pertinent to population productivity and fishery sustainability will be used to identify preferred management options that provide significant improvement in performance metrics in comparison with present-day management.

\section{Materials and methods}

\section{Description of the model used for management strategy evaluation}

The spatially explicit fishery economics simulator (SEFES) is an individual-based model of a temporally and spatially variable stock of Atlantic surfclam harvested by a fleet of individual commercial vessels (Fig. 2). The primary model is written in Fortran 90 and is then processed in MATLAB, ${ }^{7}$ vers. R2015B (MathWorks, Natick,

\footnotetext{
${ }^{6}$ Martell, S., B. Leaman, and I. Stewart. 2014. Developments in the management strategy evaluation process, fisheries objectives, and implications for harvest policy and decision making. IPHC Rep. Assess. Res. Act. 2013:239260. [Available from website.]

${ }^{7}$ Mention of trade names or commercial companies is for identification purposes only and does not imply endorsement by the National Marine Fisheries Service, NOAA.
} 


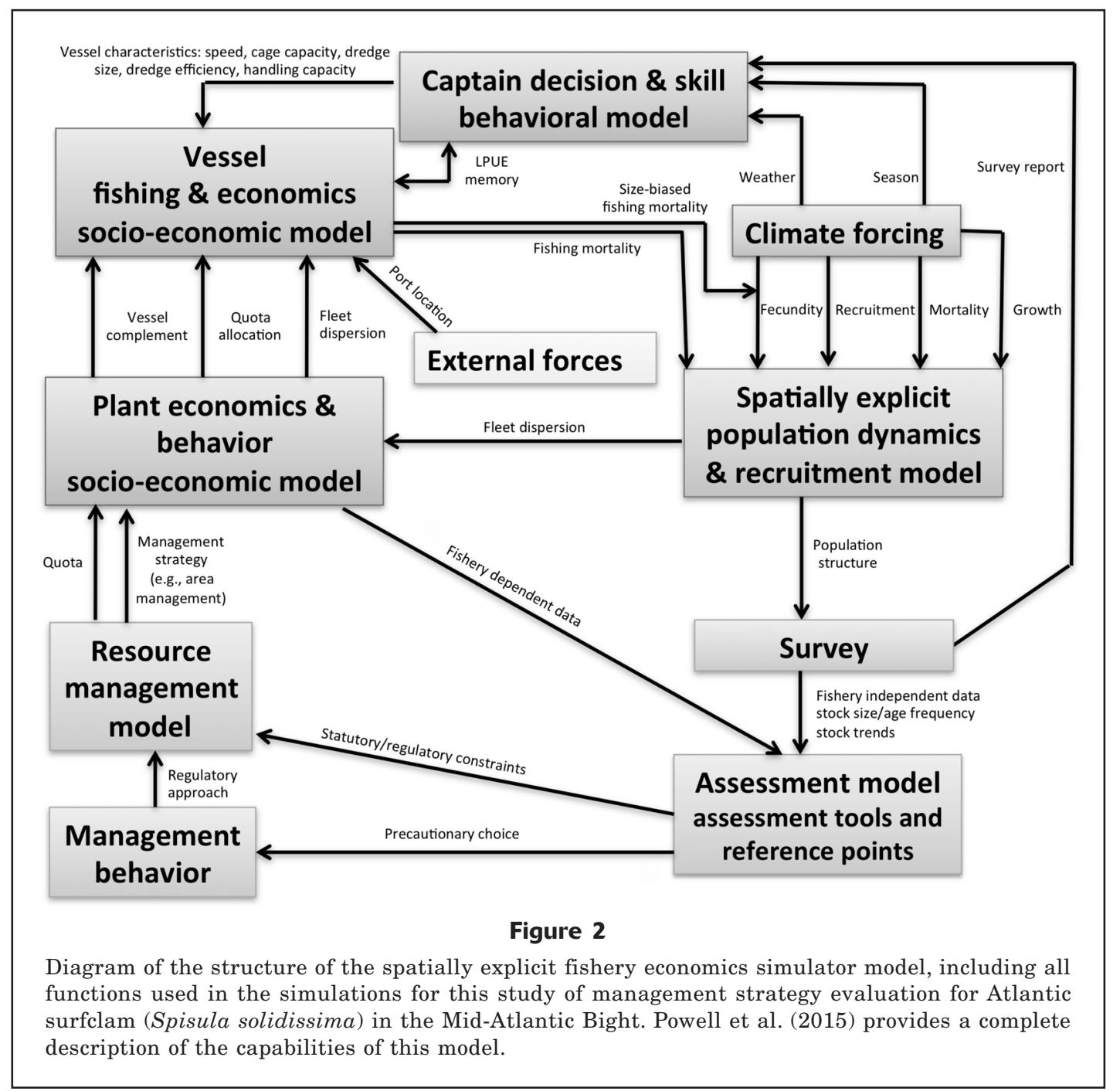

MA) and analyzed with SAS statistical software, vers. 9 (SAS Institute Inc., Cary, NC). Models that track fishing fleets spatially or seasonally are becoming increasingly important (Holland and Sutinen, 2000; Hutton et al., 2004; Mahévas and Pelletier, 2004; Monroy et al., 2010; van Putten et al., 2012). The SEFES model permits simulation of the entire fishing fleet and each vessel operating independently according to specified criteria. Powell et al. (2015) provide a detailed model description. Pertinent details for this study are summarized here.

The spatial domain of the model consists of a rectangular grid of cells with areas of $10^{\prime}$ of latitude by $10^{\prime}$ of longitude. The $10^{\prime}$-square resolution of these cells corresponds with the resolution of data reported in logbooks (NEFSC ${ }^{2}$. The grid, which is specified for the MAB, consists of 17 cells in the east-west dimension and 26 cells in the north-south dimension. Each cell, or $10^{\prime}$ square, is classified as land, fishable area, or unfishable area by a spatial mask. Three land cells specify the location of home ports located from north to south at 1) Oceanside, New York, 2) Atlantic City, New Jersey, and 3) Point Pleasant, New Jersey. Of the 400 ocean cells, 52 are fishable areas and the remaining cells are areas presently poorly inhabited or uninhabited by Atlantic surfclam (Fig. 3).

Active agents of the model are the 19 commercial vessels that harvest Atlantic surfclam under imposed operational constraints and decisions from the vessel captain. Operational constraints, which can vary among vessels, include vessel speed, maximum allowed time at sea, harvest capacities, and imposed harvest quotas. Each active vessel in the fleet is specified uniquely in the model and is committed to 1 of 3 home ports on the basis of location where that vessel usually offloads its catch. The commercial vessels travel within the spatial domain and harvests Atlantic surfclam based on decisions by the captains of where trip quotas can be met most efficiently (i.e., shortest time to fill the vessel with the lowest operational costs). The captains' decisions are based on "memories" that are built from information regarding LPUEs 
A

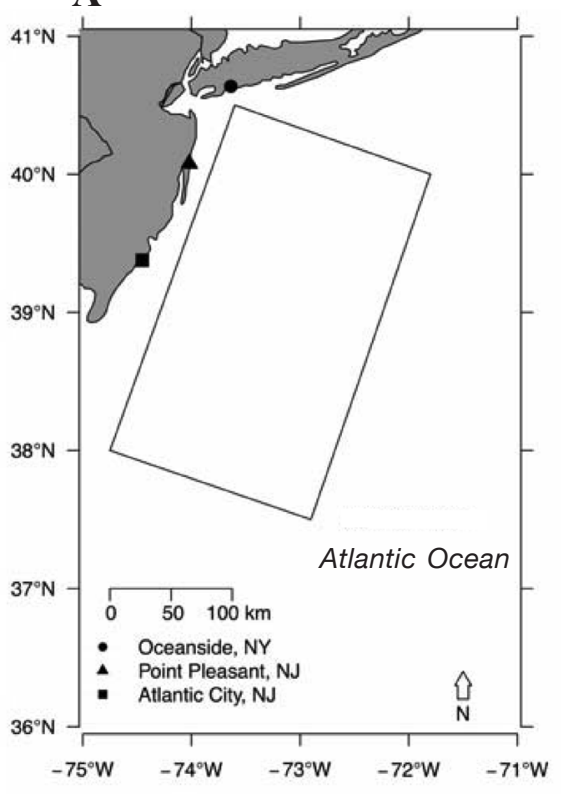

B

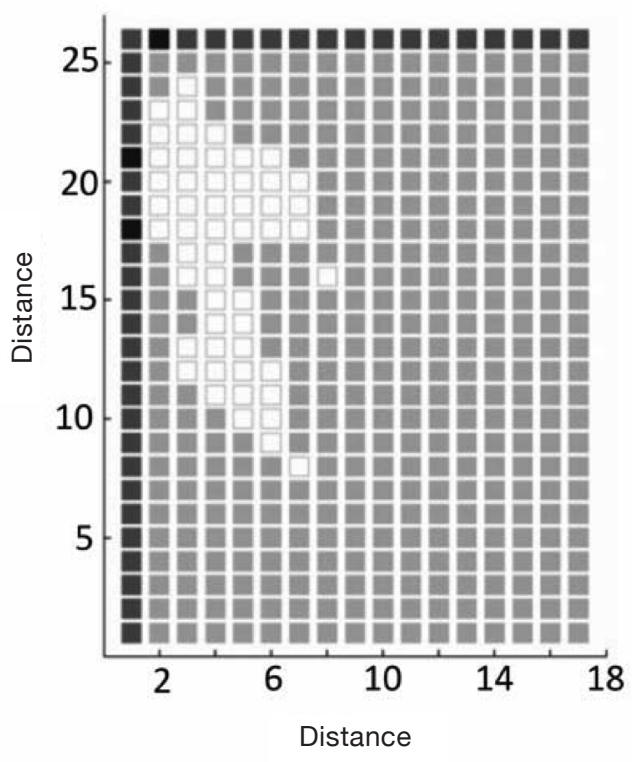

Figure 3

(A) Map showing the location of home ports and a representation of the model domain outlined for this study of management strategy evaluation for Atlantic surfclam (Spisula solidissima) in the Mid-Atlantic Bight. (B) Model domain with ports (black squares), fishable areas (white squares), unfishable areas (light gray squares), and land (dark gray squares). Each cell in the domain has a resolution of $10^{\prime} \times 10^{\prime}$. The domain contains $5210^{\prime}$ squares available to the fishery (white squares). Distance represents distances along the $x$ and $y$ axis of ten-minute squares in the grid.

for $10^{\prime}$ squares that were fished. The memory of LPUE for a $10^{\prime}$ square fished during a trip is updated after each trip. Over time a captain's memory of the entire domain degrades as the stock changes because the captain has up-to-date information only for recently fished $10^{\prime}$ squares. Each captain has a skill level that can range from 1 to 10 in the model-a level that determines the amount of time the dredge is actively fishing with 10 representing $100 \%$. All captains in this study had a skill level of 10. See Powell et al. (2015) for a more detailed description of "captain memory development" and skill levels.

Each simulation spans a total of 201 years. The time step is given in days and certain fishing activities are time-stepped in hours, and data for evaluation of performance metrics are collected annually. Model days are converted to calendar dates to allow for seasonal variability in weather and fishing behaviors (e.g., fewer trips during winter months). No fishing occurs in the first 100 years of each simulation to allow the Atlantic surfclam population to reach equilibrium with specified characteristics, such as abundance and distribution of individuals that are based on larval survival. After this period of time, the population is near carrying capacity and is characterized by a locally patchy distribution with regional characteristics consistent with the latitudinal and cross-shelf temperature gradients. The next 25 years represents historical fishing. During this time, a captain's memories of stock distribution and LPUE develops and the stock is fished down to a desired specified level. Area management is imposed in year 126 and the final 76 years are used to evaluate the area management option (i.e. the combination of closure location rule and closure duration used) in relation to present-day management.

Three initial stock distributions ranging from dense to sparse levels of patchiness were specified to cover a range in stock patchiness. Patchiness was established by assigning new recruits to each $10^{\prime}$ square by using a negative binomial random distribution that produced distinctive variance in the abundance of clams in each $10^{\prime}$ square relative to the mean abundance for all $10^{\prime}$ squares. Variation in patchiness of the distribution is included in this study as a sensitivity analysis with a range that is typical of bivalve populations and consistent with Northeast Fisheries Science Center Atlantic surfclam and ocean quahog (Arctica islandica) survey data. An Allee effect was not included; population densities are assumed not to limit fertilization efficiency. Recruitment is an annual event. The recruitment rate is set by a broodstock-recruitment relationship (Powell et al., 2015) that results in levels of postsettlement abundance that are representative of present-day abundance that is based on data from the Northeast Fisheries Science Center 2011 Atlantic surfclam and ocean quahog survey. 
Atlantic surfclams are distributed in length-based size classes. Average wet weights $(W)$ are calculated with an allometric relationship of the form (Marzec et al., 2010):

$$
W=a L^{\mathrm{b}},
$$

where $L=$ the length in millimeters.

Parameter values come from Marzec et al. (2010). Growth and mortality rates vary latitudinally and across-shelf for each $10^{\prime}$ square. The growth rate of Atlantic surfclam is calculated from a von Bertalanffy growth curve (with a growth rate $(k)$ that increases in the northern and eastward direction) by using the following equation:

$$
L_{\mathrm{A}}=L_{\infty}\left(1-e^{-k A}\right),
$$

where $L=$ length in millimeters; and

$$
A=\text { age in years. }
$$

Parameters are based on Munroe et al. (2016) and NEFSC $^{2}$. Natural mortality is imposed by using a constant mortality rate across all size classes consistent with the presently accepted stock assessment model (NEFSC ${ }^{2}$ ) and the analysis of Weinberg (1999) and is specified to increase from northeast to southwest across the domain to reduce Atlantic surfclam abundance at the southern and inshore extremes of the range as observed.

A survey of the simulated clam population is conducted annually on 1 November and includes the most recent recruitment event. The true clam density for each $10^{\prime}$ square is used for this survey and samples are taken from every $10^{\prime}$ square in the domain. Results from the survey are then used to set the annual quota based on a quota cap established by the fishery management plan (FMP) for the Atlantic surfclam $\left(\mathrm{MAFMC}^{8}\right)$, the presently accepted biological reference points $\left(\mathrm{NEFSC}^{2}\right.$ ), and the allowable biological catch control rules. The annual quota biomass is then converted to bushels of clams. In practice, the Atlantic surfclam allowable biological catch has always been above the FMP quota cap. The stock has never been overfished and overfishing has never occurred. Consequently, in these simulations, the total allowable catch remained stable at the FMP quota cap of 3.5 million bushels. Thus, simulations address management options for a fishery in which overfishing does not occur and for which the stock is not overfished-simulations consistent with the conditions present throughout the 2000 to 2012 period as documented in the most recent federal assessment $\left(\mathrm{NEFSC}^{2}\right)$.

For the current FMP for Atlantic surfclams, an individual transferable quota system is used that allocates a number of cage landings to each of the shareholders

\footnotetext{
8 MAFMC (Mid-Atlantic Fishery Management Council). 1986 Amendment \#6 to the fishery management plan for Atlantic surf clam and ocean quahog fisheries, rev. ed., 102 p. MidAtlantic Fishery Management Council, Dover, DE [Available from website.]
}

(McCay et al., 1995; MAFMC $^{9}$; NEFSC ${ }^{2}$ ). In practice, these shares are amassed through direct ownership or lease by processing plants and quotas are issued to the vessels each of which fishes exclusively for specific processing plants. That is, the fishery is vertically integrated with processing plants holding quotas that they distribute to vessels that land catch only at designated ports. Within this model, the current FMP is implemented and area management is added to the management plan. Each processing plant distributes its fraction of the total quota to its vessels weekly. The weekly quota is limited to twice the vessel hold size serving to limit the number of trips per vessel to 2 trips/week, a number consistent with industry practice. During each simulation, a vessel harvests clams on the basis of the captain's decision and memory of fishing areas and according to imposed harvest quotas. The vessels fish to capacity if possible, given the constraint that time at sea is restricted during the warmer months to limit deterioration of the catch because Atlantic surfclam vessels have no or a limited capacity for refrigeration. Captains' memories are updated after each fishing trip. Harvest rates are calculated from tow speed, dredge width, dredge efficiency, the size selectivity of the dredge, and the skill of the captain. Tow speed, dredge width, dredge efficiency, and the size selectivity of the dredge are based on federal survey program data reported from 2011 (e.g., $\mathrm{NEFSC}^{2}$ ) and data received in 2013 from vessel owners and captains on standard operating conditions for harvesting Atlantic surfclam.

\section{Simulation experiments}

The essential elements of an MSE include management objectives, performance metrics, and management options (Smith, 1994). The primary management objective is to insulate both the Atlantic surfclam stock and the commercial LPUE from further decline. The evaluation of alternative management procedures for both the enhancement of the Atlantic surfclam stock and the economics of the industry is based on statistical analysis of performance metrics. The performance metrics are rooted in interviews with representatives from processing plants, industry trade organizations, and vessel captains to ensure appropriateness. The performance metrics chosen are important in that they provide metrics that allow commercial stakeholders to evaluate the results of each management procedure based on their business model. A total of 5 performance metrics were used. Two of these metrics are used to measure the population: clam whole-stock density, which is the number of clams $\geq 120 \mathrm{~mm}$ SL per square meter (the fishable stock is defined as clams $\left.\geq 120 \mathrm{SL} \mathrm{mm} \mathrm{[NEFSC}{ }^{2}\right]$ ), and the number of clams per bushel. Three metrics were used to measure the effect of area management on the

\footnotetext{
${ }^{9}$ MAFMC (Mid-Atlantic Fishery Management Council). 2013. Atlantic surfclam information document, 9 p. MidAtlantic Fishery Management Council, Dover, DE. [Available from website, accessed September 2014.]
} 
commercial industry: 1) LPUE, which is the number of bushels fished per hour; 2) the number of $10^{\prime}$ squares fished; and 3) the total distance traveled per fishing trip (in kilometers). The location of ports and processing plants are invariable, consistent with present-day economic limitations that make the movement of processing capacity an implausible adaptation. The management options include a range of closure locations and durations discussed later in this section.

Alternative hypotheses about population dynamics, often termed "states of nature," such as dispersion and abundance of a stock, can cause marked differences in the density and disposition of a stock and influence the success of management alternatives (Punt and Hilborn, 1997; McAllister and Kirkwood, 1998; Hilborn, 2003). In this study, variations in stock distribution are simulated as differing degrees of patchiness obtained by increasing the ratio of the variance in recruitment among $10^{\prime}$ squares to the mean recruitment for the entire population, with each degree being a variance-to-mean ratio approximately twice the value of the previous one (e.g., medium patchiness has a variance-to-mean ratio that is approximately twice that of low patchiness). Stock abundance is representative of present-day abundance in 2011 (NEFSC $^{2}$ ) based on abundance data from the Northeast Fisheries Science Center Atlantic surfclam and ocean quahog survey in 2011 (NEFSC $^{2}$ ).

Incidental mortality of clams that remain on the sea floor after dredging is investigated by setting incidental mortality to $0 \%$ and $20 \%$ of the clams encountered by the dredge but not caught in the dredge. The assumption that is currently made by NMFS is that incidental mortality occurs at an intermediate value of approximately $12 \%$ (NEFSC ${ }^{2}$ ) based on Meyer et al. (1981). For each of the degrees of patchiness and for the 2 levels of incidental mortality, simulations were performed with present-day management (termed "base cases" hereafter) for a comparison with simulations of area management options.

Incorporation and manipulation of various commercial procedures allow an investigation of the fishery and the plausible options for enhancement of economic opportunities. Captain behavioral types, closure durations, closure locations, and years to harvest (i.e., the elapsed time for a small clam of specified size to reach a defined market size) have all been identified as pertinent commercial features when considering management strategies. Commercial procedures are based on interviews conducted with industry leaders, including representatives from processing plants and trade organizations, and vessel captains.

One of 3 captain behavioral types (standard, survey, confident) is included in each simulation. Captain behaviors are exclusive to each captain type (e.g., confident captains do not use survey data). Standard captains do not search for new fishing grounds and do not use survey data. Survey captains update their knowledge every 3 years with data from NMFS population surveys. The use of NMFS survey data by captains is common practice and has been found to improve per- formance in simulation studies (Powell et al., 2015). Confident captains spend $20 \%$ of fishing time searching for new fishing grounds. In simulations, searching behavior produces similar positive changes in performance because using survey data (Powell et al., 2015) and searching is reported as a desirable practice by captains. Each individual simulation has a defined degree of stock patchiness and captain type (Table 1). Nine simulations, 1 simulation for each combination of captain type and stock patchiness, constitute 1 set of cases, hereafter termed an ennead (Fig. 4).

Hypotheses of this study are that area management will be beneficial for the Atlantic surfclam stock and commercial fishery. A comparison of performance metrics between enneads under present-day and those under alternative management allowed us to test our hypotheses (Fig. 5). Management alternatives consist of closures of one 10' square per year during the 76 simulated fishing years. The management alternatives simulate the addition of area closures to the current management plan. Area closure locations are based on 1 of 2 rules; a given rule remains in effect throughout the 76 simulated fishing years. If rule 1 is executed, the $10^{\prime}$ square with the highest ratio of the number of small clams to the number of market-size clams is closed each year. Rule 1 focuses on the importance of the proportional presence of small clams. If rule 2 is imposed, the $10^{\prime}$ square with the largest density of small clams (number of clams per square meter) is closed each year. Rule 2 considers the population of small clams as a whole over an area. Closure durations of 3,5 , and 7 years are compared with no closures. This results in 3,5 , or $710^{\prime}$ squares being closed during each of the simulated years once the initial span of time specified has elapsed. The closure durations would result in $6 \%, 10 \%$, and $14 \%$, respectively, of the fishable area being closed in any year after the maximum number of $10^{\prime}$ squares were closed (e.g., for the 5-year closure duration, five $10^{\prime}$ squares [10\% of the fished area] would be closed at a given time).

Success of both of the area management rules for closure location varies depending on the definition of a small clam (i.e., a clam that is smaller than market size). The definition of a small clam implemented in the simulations is a value that depends on the time required for a clam to grow to market size $(120 \mathrm{~mm} \mathrm{SL}$; NEFSC $^{2}$ ). The specified size depends on growth rate, which is variable across the domain. This variation allows clams to grow faster in some regions than in others, depending on water temperature. A range of years (from 2 to 5 years) to reach harvest size is investigated in this study. The number of small clams is determined on the basis of the smallest SL that would reach market size (120 mm SL) in a defined period of time. All clams with SL that would reach market size, or larger, in the defined amount of time in a $10^{\prime}$ square, but $<120$ $\mathrm{mm}$ SL (i.e., less than market size), are counted to invoke closure location rule 1 or 2 depending on which rule is being used for a given set of simulations. For convenience, an average of the minimum sizes for all 


\section{Table 1}

Varying characteristics of model simulations used in the management strategy evaluation for the Atlantic surfclam (Spisula solidissima) in the Mid-Atlantic Bight. The structure of each set of cases is shown in bold. Incidental mortality applies to clams that are not retained by the dredge. Nine individual simulations (in bold) represent one set of cases, an ennead (see also Fig. 4). An ennead was run for each level of incidental mortality, each management option, each closure duration, and each definition of a small clam for a total of $72(2 \times 3 \times 3 \times 4)$ enneads. Market-size clams are $\geq 120 \mathrm{~mm}$ shell length (SL). LPUE is measured as number of bushels fished per hour. Three initial stock distributions ranging from dense to sparse levels of patchiness were specified to cover a range in stock patchiness. Patchiness was established by assigning new recruits to each $10^{\prime}$ square by using a negative binomial random distribution that produced distinctive variance in the abundance of clams in each $10^{\prime}$ square relative to the mean abundance for all $10^{\prime}$ squares.

\begin{tabular}{|c|c|c|c|c|c|c|}
\hline \multirow[b]{2}{*}{$\begin{array}{l}\text { Performance } \\
\text { metrics }\end{array}$} & \multicolumn{4}{|c|}{ Model configurations } & \multicolumn{2}{|c|}{ Ennead complement } \\
\hline & $\begin{array}{c}\text { Levels of } \\
\text { incidental } \\
\text { mortality }\end{array}$ & $\begin{array}{c}\text { Management } \\
\text { options }\end{array}$ & $\begin{array}{l}\text { Closure } \\
\text { duration } \\
\quad(\mathrm{yr})\end{array}$ & $\begin{array}{l}\text { Definitions } \\
\text { of a small } \\
\text { clam }\end{array}$ & Patchiness & $\begin{array}{l}\text { Captain } \\
\text { type }\end{array}$ \\
\hline $\begin{array}{l}\text { Stock density } \\
\quad \text { (number of clams } \\
\left.\geq 75 \mathrm{~mm} \mathrm{SL} / \mathrm{m}^{2}\right)\end{array}$ & $0 \%$ & Present-day-no closures & 3 & $104 \mathrm{~mm}$ SL & High & $\begin{array}{c}\text { Standard } \\
\text { Confident } \\
\text { Survey }\end{array}$ \\
\hline $\begin{array}{l}\text { Number of clams } \\
\text { per bushel }\end{array}$ & $20 \%$ & $\begin{array}{l}\text { Rule } 1-\text { close the } 10^{\prime} \text { square } \\
\text { with the highest ratio of the } \\
\text { number of small clams to the } \\
\text { number of market-sized clams }\end{array}$ & 5 & $93 \mathrm{~mm} \mathrm{SL}$ & Medium & $\begin{array}{c}\text { Standard } \\
\text { Confident } \\
\text { Survey }\end{array}$ \\
\hline LPUE (bushels/h) & & $\begin{array}{l}\text { Rule } 2 \text {-close the } 10^{\prime} \text { square } \\
\text { with the highest number of } \\
\text { small clams } / \mathrm{m}^{2}\end{array}$ & 7 & $80 \mathrm{~mm} \mathrm{SL}$ & Low & $\begin{array}{l}\text { Standard } \\
\text { Confident } \\
\text { Survey }\end{array}$ \\
\hline $\begin{array}{l}\text { Number of } 10^{\prime} \text { squares } \\
\text { fished } \\
\text { Distance traveled } \\
\text { during fishing }(\mathrm{km})\end{array}$ & & & & $64 \mathrm{~mm} \mathrm{SL}$ & & \\
\hline
\end{tabular}

$10^{\prime}$ squares is used to identify groups of clams with the same maximal elapsed time to market size for our presentation of simulation results. These averages are 104, 93, 80, and $64 \mathrm{~mm}$ SL for 2, 3, 4, and 5 growth years, respectively, to reach $120 \mathrm{~mm}$ SL.

\section{Statistical evaluation of alternative management strategies}

Each comparison between present-day and alternative management is based on an ennead of simulations with varying captain behavior and patchiness of recruitment (Table 1) for each defined size of a small clam and each specified closure duration. This results in 4 enneads per closure duration ( 1 set of 9 for each definition of a small clam) and 12 enneads per closure location rule (Fig. 4). The structure of the base case is composed of the same states of nature and captain behaviors as the alternative management cases, excluding area closures. Each ennead is designed to evaluate the interaction of patchiness of distribution with captain behavior in order to evaluate the sensitivity of outcomes to this key interaction.

Management strategies were compared by using the nonparametric Wilcoxon signed-rank test (Conover, 1980). This test uses the difference in metric values between 2 outcomes-in this case the difference between the base case and the otherwise equivalent simulation under alternative management (e.g., closure location rules 1 and 2, closure durations, and small clam definitions (i.e., years to market size, Fig. 5). Each comparison was based on 76 years of simulated time, with 1 difference calculated for each of the 76 years; therefore, a single Wilcoxon test was based on $n=76$ (Fig. 6). Because each year was different from each succeeding or preceding year because a $10^{\prime}$ square was opened and closed each year and because each vessel and captain operated independently in each year with their own behaviors and differing memories, each year represented a unique pairwise comparison of the area management option and the otherwise equivalent base case. Therefore, 9 Wilcoxon tests were conducted for each ennead. The likelihood of the number of significant outcomes from these 9 tests exceeding chance was evaluated by an exact binomial test (Conover, 1980). Any comparison yielding more than 1 significant difference between the base case and area management option out of the 9 simulations performed exceeded the number expected by chance at $\alpha=0.05$.

Performance metrics were evaluated by the proportion of simulations that resulted in an increased performance metric in comparison with the base case with the same composition and the amount of increase seen in those significant simulations. Management strate- 


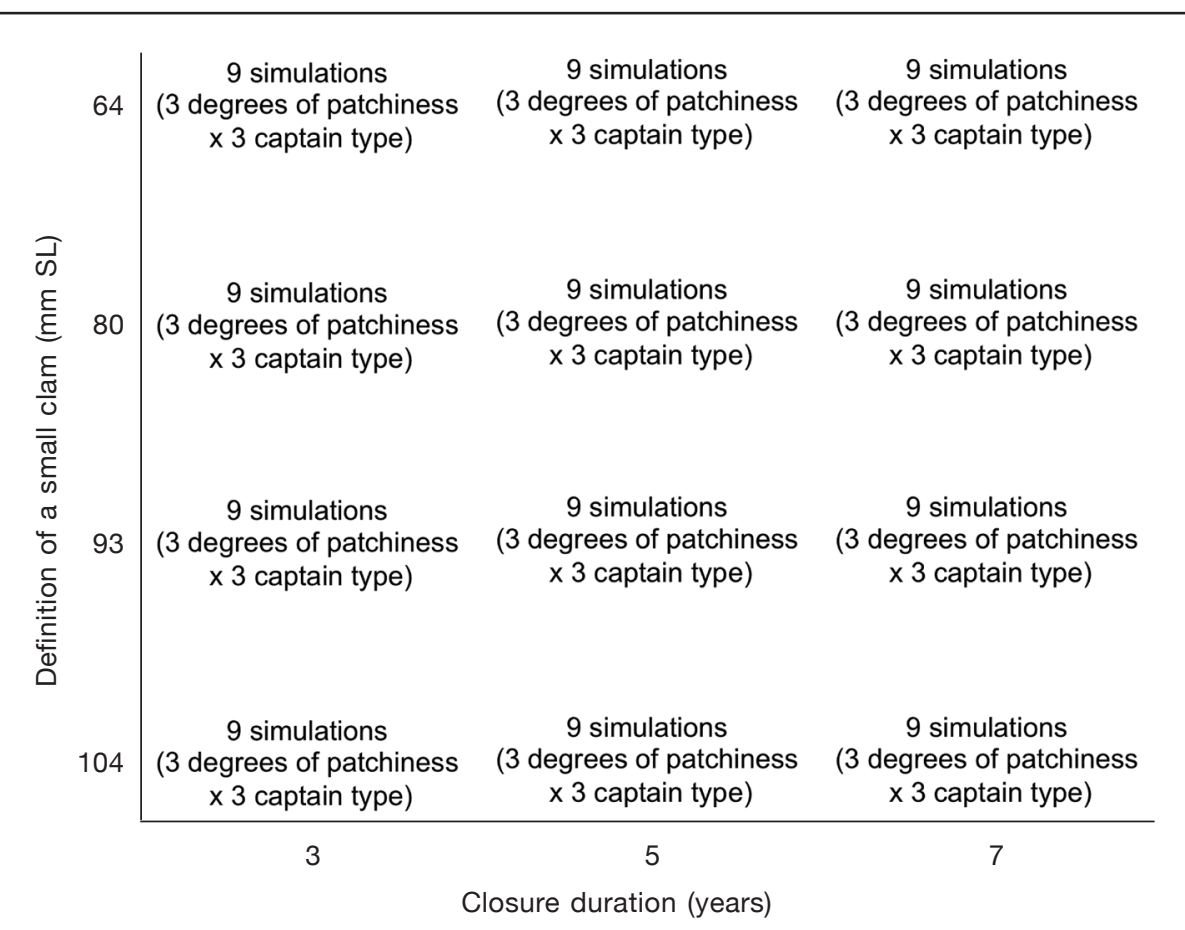

Figure 4

Matrix design for the sets of simulations used in pairwise comparisons of performance metrics for this study of the management strategy evaluation for the Atlantic surfclam (Spisula solidissima) in the Mid-Atlantic Bight. The matrix is repeated for each of the 2 closure location rules (rule 1: ratio of the number of small clams to the number of market-size clams; Rule 2: number of small clams per square meter). The increase in degree of patchiness approximately doubles between each level (i.e., the most patchy distribution is twice as patchy as the intermediate degree of patchiness). The 3 captain types are standard (does not search or use survey data), survey (uses survey data but does not search fishing grounds), and confident (searches but does not use survey data). Definitions of a small clam are given as of clams is given as shell length (SL) in millimeters. gies that result in a large proportion of simulations that showed improvement in comparison with the base case (even if the proportional increase is small) are preferable because the scenario would be more likely to result in improvements if implemented than a scenario with few simulations showing improvement; that is, improvement can be expected over a wider range of contingencies influenced by differential recruitment patterns and captains' behaviors. It is possible that management decisions could be based on a large amount of increase even though the possibility of that outcome is low. For this reason, investigation of the possibility of the outcomes and the magnitude of the changes seen are included in this study. In addition to a comparison of the sets of alternative management and base cases, a second series of comparisons was conducted between alternative area management strategies; these offer additional insight as to which management options offer the most benefit.

In certain scenarios, a 4-year closure duration was examined in addition to the 3-, 5-, and 7-year closures.
The performance metric values for the 4-year closure duration routinely fell between the 3- and 5-year closure durations performance metric values as seen in the number of clams per bushel and LPUE included in Table 2 as examples for comparison with simulation results discussed subsequently. For this reason, results of simulations with the use of the 4-year closure duration will not be presented subsequently.

\section{Results}

Closure location based on rule 1: the ratio of small clams to market-size clams

Stock density A greater proportion of simulations show a significant increase in stock density when the definition of a small clam was $93-120 \mathrm{~mm}$ SL or $80-120 \mathrm{~mm}$ SL (Table 3), which is representative of clams expected to reach market size $(120 \mathrm{~mm}$ SL) in $\leq 3$ and $\leq 4$ years respectively. As the duration of the closure increased 


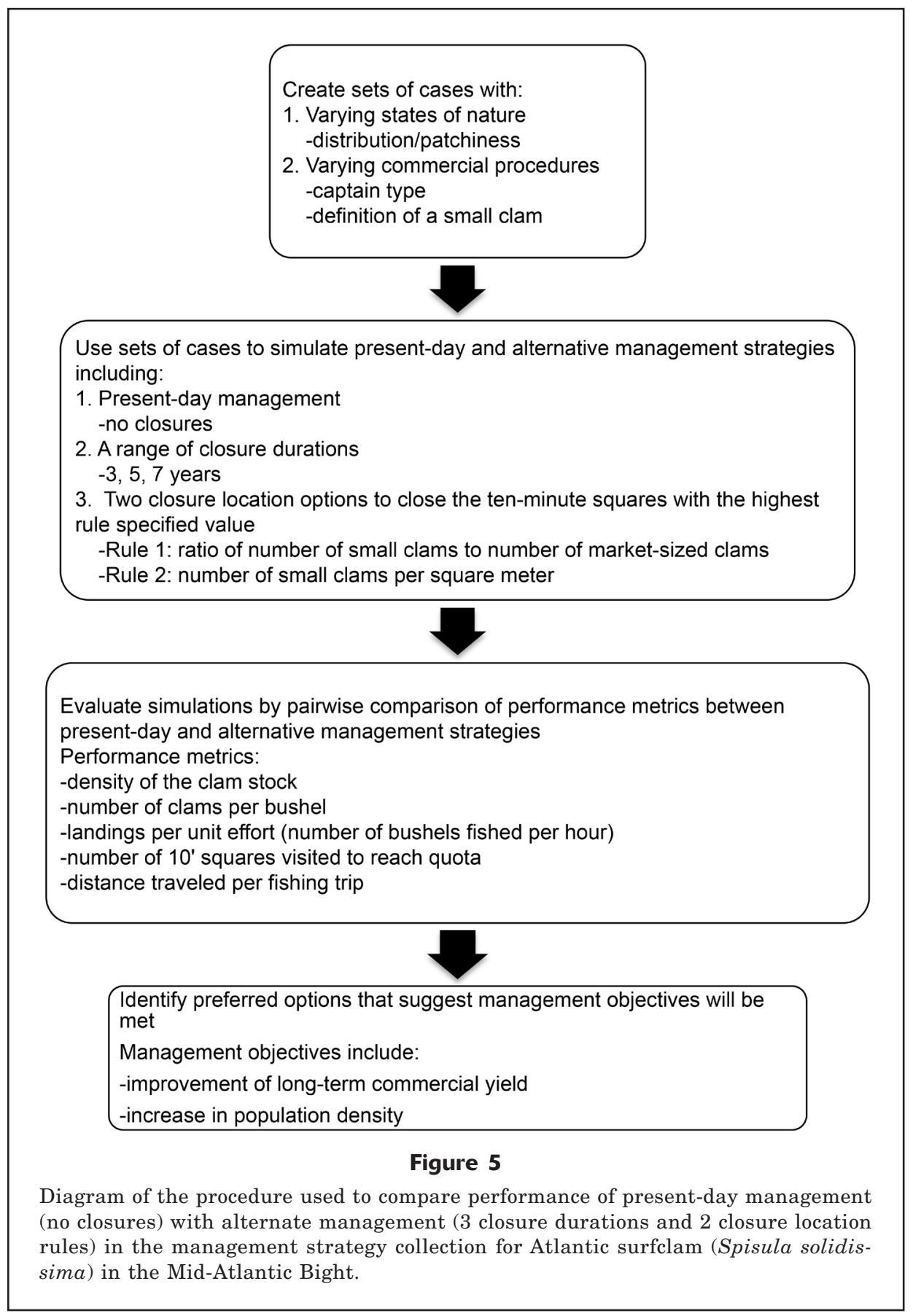

from 3 to 7 years, the average percentage of simulations with significant increases in stock density under area management increased across all definitions of a small clam. The 3-year closure duration resulted in an average increase in stock density of $5 \%$ (Fig. 7, Table 4); $44 \%$ (Table 3) of simulations showed a significant increase in stock density compared to present-day management. The 5-year closure duration resulted in an average $4 \%$ increase in stock density over all definitions of a small clam (Fig. 7, Table 4). The greatest average percentage of simulations that showed a sig- nificant increase in stock density compared with that under present-day management is seen with the 5-year closure duration (range: 33-67\%; average: 47\%; Table 3 ). The 7-year closure duration resulted in a $7 \%$ average increase in stock density (Fig. 7, Table 4), the largest average stock density increase across all definitions of a small clam. The 7-year closure duration showed a significant increase in stock density in an average of $44 \%$ (range: $33-56 \%$; Table 3 ) of the simulations in comparison with present-day management. When the imposed incidental mortality on clams not retained 
Simulation of 76 years under present-day management (ITQ system)

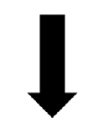

Annual data collected (performance metrics) $(n=76)$

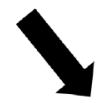

Simulation of 76 years under alternative management (addition of area management via closures to the ITQ system)

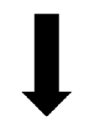

Annual data collected (performance metrics) $(n=76)$

Pair-wise comparisons of performance metrics via Wilcoxon signed-rank test

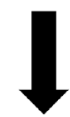

Identification of preferred option

(simulations that result in improvement to the Atlantic surfclam stock and commercial fishery via improvement in performance metrics: density of the clam stock, number of clams per bushel, landings per unit effort [number of bushels per hour], number of 10 ' squares visited to reach quota, distance traveled per fishing trip)

\section{Figure 6}

Diagram of the methods used to identify a preferred option to meet management objectives (i.e., improvement in the biomass of the Atlantic surfclam (Spisula solidissima) stock and economic opportunities of the commercial fishery in the Mid-Atlantic Bight). ITQ=individual transferrable quota.

by the dredge is increased from $0 \%$ to $20 \%$, a higher percentage of simulations show significantly increased stock density and the degree of increase in stock density was also larger (Table 5). The increase in stock density with an increase in incidental mortality can be explained by the fact that without closures (i.e., under present-day management), small clams are subjected to additional mortality over the entire stock. Because of the closure rules, the fishery is shifted from regions where mortality on small clams would be most significant to areas of lesser impact because fewer small clams reside there. A closed 10' square offers protection to the clams inside it until that $10^{\prime}$ square is reopened to the fishery, and these $10^{\prime}$ squares are characterized by a disproportionate number of small clams. As a consequence, the total mortality on small clams over the entire stock is reduced and stock density commensurately increases.

Number of clams per bushel As the closure duration increased from 3 to 7 years, fewer clams were required to fill a bushel. Having fewer clams per bushel suggests that larger clams are landed under alternative management and that as the duration of the closure increased, the size of landed clams increased. The percentage of simulations that showed significantly more clams per bushel under present-day management reached $100 \%$ (Table 3) for all 5-year and 7-year closure durations.
The number of clams per bushel was on average $4 \%$ greater under present-day management than under the 7-year closure duration (Fig. 7, Table 4). The increased clam size as the duration of the closure increased was not affected by an increase in incidental mortality (Table 5).

Landings per unit of effort As the size defining a small clam decreased, a greater proportion of simulations had significant LPUE increases under the 5- and 7-year closure durations in comparison with LPUE under present-day management. The proportion of clams in the stock defined as small increased as the size defining a small clam decreased. For example, as the definition of a small clam changed from $93-120 \mathrm{~mm}$ SL to 80-120 mm SL, more clams in the population are defined as small because the clams between 92 and $80 \mathrm{~mm}$ SL are now added to the number of clams deemed to be small. The LPUE declines when the size definition increases from $80-120 \mathrm{~mm}$ SL to $93-120$ $\mathrm{mm}$ SL. The $10^{\prime}$ squares with the highest clam density, which are now dominated by fewer small clams when the 93-120 mm SL definition is used, are being closed on the basis of the closure location rule (close 10' square with largest ratio of the number of small clams to the number of market-size clams). Thus, more clams are protected when the definition of a small clam is smaller (i.e., 80$120 \mathrm{~mm}$ SL) which leads to a larger number of clams in the stock when the $10^{\prime}$ square reopens.

All of the examined closure durations resulted in average increases of $6 \%$ in LPUE (Fig. 7, Table 4). The 3 -year closure duration resulted in $61 \%$ (Table 3 ) of simulations showing a significant increase in LPUE compared with that under present-day management. The 5-year closure duration had the highest average percentage of simulations that showed a significant increase in LPUE compared with LPUE under present-day management (range: 33-89\%; average: 64\%; Table 3). The 7-year closure duration had the lowest average percentage of simulations showing a significant increase in LPUE in comparison with that under present-day management (range: 33-56\%; average: $44 \%$; Table 3 ). When additional incidental mortality is imposed, the effect of alternative management in increasing the LPUE is enhanced (Table 5). The 5-year closure duration resulted in an average $15 \%$ increase in LPUE, and $75 \%$ of simulations had significantly increased LPUE in comparison with that under presentday management (Table 5).

Number of $10^{\prime}$ squares fished The number of $10^{\prime}$ squares fished during a year increased as the closure duration decreased (Fig. 7, Table 4) because captains are targeting $10^{\prime}$ squares that recently opened after be- 
Table 2

Summary statistics for average proportion differences for the number of clams per bushel and landings per unit of effort (LPUE), measured as the number of bushels fished per hour and given as examples of the results for the model that used the 4-year closure duration in an evaluation of management strategy for the Atlantic surfclam (Spisula solidissima) in the Mid-Atlantic Bight. Comparison can be made with data in Table 6. Size of clams is given as shell length (SL) in millimeters, and closure duration is measured in years. $N$ is the number of simulations where a significant difference exists between the performance metric under present-day or alternative management at present-day abundance. The maximum $N$ is 9 .

\begin{tabular}{|c|c|c|c|c|c|c|c|c|c|c|c|c|c|c|c|c|c|}
\hline & & \multicolumn{16}{|c|}{ Definition of a small clam } \\
\hline & & \multicolumn{4}{|c|}{$104 \mathrm{~mm} \mathrm{SL}$} & \multicolumn{4}{|c|}{$93 \mathrm{~mm} \mathrm{SL}$} & \multicolumn{4}{|c|}{$80 \mathrm{~mm} \mathrm{SL}$} & \multicolumn{4}{|c|}{$64 \mathrm{~mm} \mathrm{SL}$} \\
\hline & & \multicolumn{16}{|c|}{ Closure duration (yr) } \\
\hline & & 3 & 4 & 5 & 7 & 3 & 4 & 5 & 7 & 3 & 4 & 5 & 7 & 3 & 4 & 5 & 7 \\
\hline \multicolumn{18}{|l|}{ Number of clams per bushel } \\
\hline \multirow{2}{*}{ Present management } & $N$ & 5 & 9 & 9 & 9 & 2 & 9 & 9 & 9 & 2 & 5 & 9 & 9 & 2 & 3 & 9 & 9 \\
\hline & $\chi^{2}$ & 0.01 & 0.02 & 0.03 & 0.04 & 0.01 & 0.02 & 0.03 & 0.04 & 0.01 & 0.01 & 0.02 & 0.04 & 0.01 & 0.01 & 0.01 & 0.03 \\
\hline \multirow[t]{2}{*}{ Alternative management } & $N$ & 0 & 0 & 0 & 0 & 0 & 0 & 0 & 0 & 0 & 0 & 0 & 0 & 0 & 0 & 0 & 0 \\
\hline & $\chi^{2}$ & - & - & - & - & - & - & - & - & - & - & - & - & - & - & - & - \\
\hline \multicolumn{18}{|l|}{ LPUE } \\
\hline \multirow[t]{2}{*}{ Present management } & $N$ & 0 & 1 & 1 & 1 & 0 & 1 & 0 & 1 & 0 & 0 & 1 & 1 & 0 & 0 & 0 & 1 \\
\hline & $\chi^{2}$ & - & 0.03 & 0.04 & 0.05 & - & 0.04 & - & 0.02 & - & - & 0.05 & 0.04 & - & - & - & 0.02 \\
\hline \multirow{2}{*}{ Alternative management } & $N$ & 4 & 7 & 3 & 5 & 6 & 5 & 7 & 4 & 7 & 9 & 7 & 3 & 5 & 5 & 8 & 4 \\
\hline & $\chi^{2}$ & 0.06 & 0.09 & 0.05 & 0.06 & 0.07 & 0.07 & 0.08 & 0.12 & 0.05 & 0.05 & 0.08 & 0.12 & 0.07 & 0.05 & 0.07 & 0.09 \\
\hline
\end{tabular}

ing closed for some duration of years. A $10^{\prime}$ square that has been closed for a longer duration will result in the landing of larger clams and have a higher stock density, and therefore LPUE will be higher and lead to the vessels targeting these $10^{\prime}$ squares for a larger number of trips. Consequently, fewer 10' squares will be visited to fill quotas. Increasing the incidental mortality imposed on clams that remain after dredging resulted in a larger percentage of simulations with significantly fewer $10^{\prime}$ squares fished during the year. Increased incidental mortality also caused larger percent decreases in the number of $10^{\prime}$ squares visited under alternative management.

Distance traveled per fishing trip In an average of $24 \%$ (range: 11-33\%; Table 3) of 3-year closure simulations, the distance traveled to the fishing ground increased significantly, with an average increase in distance over all simulations of $3 \%$ (Fig. 7, Table 4). The 5-year closure duration also resulted in an average increase in distance traveled of $3 \%$ (Fig. 7, Table 4), but $47 \%$ (range: 44-56\%; Table 3) of simulations showed significantly increased distance traveled under area management. The 7-year closure duration demonstrated the highest percentage of cases having significantly greater distances traveled (average: 58\%; Table 3). Accordingly, the 7-year closure duration also resulted in the largest average percent increase in distance traveled (8\%; Fig. 7, Table 4). As closure duration increases, some of the $10^{\prime}$ squares that are closed are close to the ports; the fishery would target these otherwise. Thus travel distance increases. A longer closure duration results in more $10^{\prime}$ squares close to the ports being closed: distance traveled must increase commensurately. The average percent increase in distance traveled was $4 \%$ (Fig. 7, Table 4) for all closure durations. When incidental mortality imposed on clams that remain after dredging was increased, the percentage of simulations that had significantly greater distances traveled under area management decreased (Table 5).

\section{Closure location based on rule 2: the number of small clams per square meter}

Stock density The 3-year closure duration resulted in an average increase of $4 \%$ in stock density (Fig. 8, Table 6), but an average of only 36\% (range: 33-44\%; Table 7 of simulations showed significantly increased stock density compared with that under present-day management. The 5-year closure duration resulted in an average increase in stock density of $4 \%$ (Fig. 8). The 5-year closure duration also had the highest average percentage of simulations that showed a significant stock density increase compared to present-day management (range: 33-67\%; average: 50\%; Table 7). The 7-year closure duration resulted in a $5 \%$ average increase in stock density (Fig. 8). On average, the 7-year closure duration showed significant increases in stock density in only $39 \%$ (range $0-56 \%$; Table 7 ) of the simulations in comparison with present-day management. An increase in incidental mortality enhances the effect of alternative management (Table 8 
Table 3

Evaluation of model simulations in which closure location rule 1 was used to examine the influence of area management on the stock and commercial fishery of Atlantic surfclam (Spisula solidissima) in the Mid-Atlantic Bight. Tabulated are the proportion of simulations where metrics used to evaluate the Atlantic surfclam population and commercial fishery were significantly greater under present-day management or alternative management under closure location rule 1 and with present-day abundance. Rule 1 mandates that the cell with the highest ratio of the number of small clams to the number of market-size clams be closed each year. There were 9 simulations per percentage. Any fraction over 0.11 ( 1 significant difference out of 9 ) is unlikely to occur by chance (exact binomial test: $\alpha=0.05$; Conover, 1980). Size of clams is given as shell length (SL) in millimeters, closure duration is measured in years, and LPUE means landings per unit of effort.

\begin{tabular}{|c|c|c|c|c|c|c|c|c|c|c|c|c|}
\hline & \multicolumn{12}{|c|}{ Definition of a small clam } \\
\hline & \multicolumn{3}{|c|}{104 mm SL } & \multicolumn{3}{|c|}{$93 \mathrm{~mm} \mathrm{SL}$} & \multicolumn{3}{|c|}{$80 \mathrm{~mm} \mathrm{SL}$} & \multicolumn{3}{|c|}{$64 \mathrm{~mm} \mathrm{SL}$} \\
\hline & \multicolumn{12}{|c|}{ Closure duration (yr) } \\
\hline & 3 & 5 & 7 & 3 & 5 & 7 & 3 & 5 & 7 & 3 & 5 & 7 \\
\hline \multicolumn{13}{|l|}{ Stock density } \\
\hline Present management & 0.44 & 0.44 & 0.11 & 0.11 & 0.11 & 0.00 & 0.22 & 0.11 & 0.11 & 0.33 & 0.22 & 0.56 \\
\hline Alternative management & 0.44 & 0.33 & 0.56 & 0.44 & 0.67 & 0.44 & 0.56 & 0.56 & 0.44 & 0.22 & 0.33 & 0.33 \\
\hline \multicolumn{13}{|l|}{ Number of clams per bushel } \\
\hline Present management & 0.56 & 1.00 & 1.00 & 0.22 & 1.00 & 1.00 & 0.22 & 1.00 & 1.00 & 0.22 & 1.00 & 1.00 \\
\hline Alternative management & 0.00 & 0.00 & 0.00 & 0.00 & 0.00 & 0.00 & 0.00 & 0.00 & 0.00 & 0.00 & 0.00 & 0.00 \\
\hline \multicolumn{13}{|l|}{ LPUE } \\
\hline Present management & 0.00 & 0.11 & 0.11 & 0.00 & 0.00 & 0.11 & 0.11 & 0.00 & 0.11 & 0.00 & 0.00 & 0.44 \\
\hline Alternative management & 0.44 & 0.33 & 0.56 & 0.67 & 0.56 & 0.44 & 0.78 & 0.78 & 0.33 & 0.56 & 0.89 & 0.44 \\
\hline \multicolumn{13}{|l|}{ Number of $10^{\prime}$ squares fished } \\
\hline Present management & 0.44 & 0.56 & 0.67 & 0.33 & 0.44 & 0.56 & 0.44 & 0.56 & 0.44 & 0.44 & 0.44 & 0.56 \\
\hline Alternative management & 0.22 & 0.00 & 0.11 & 0.11 & 0.00 & 0.00 & 0.11 & 0.00 & 0.00 & 0.33 & 0.00 & 0.00 \\
\hline \multicolumn{13}{|l|}{ Total distance traveled } \\
\hline Present management & 0.11 & 0.00 & 0.00 & 0.11 & 0.00 & 0.00 & 0.00 & 0.11 & 0.00 & 0.11 & 0.00 & 0.00 \\
\hline Alternative management & 0.33 & 0.56 & 0.78 & 0.11 & 0.44 & 0.67 & 0.33 & 0.44 & 0.44 & 0.22 & 0.44 & 0.44 \\
\hline
\end{tabular}

resulting in average stock density increases of $7-8 \%$ over the range of closure durations and definitions of a small clam.

Number of clams per bushel As the closure duration increased, the catch contained fewer clams per bushel; however, this effect did not vary significantly with a change in the definition of a small clam. The percentage of simulations that showed significantly more clams per bushel under present-day management reached the highest average of 97\% (range: $89-100 \%$; Table 7) for 7-year closure durations. With a 7-year closure duration, the number of clams per bushel was 3\% higher under present-day management (Fig. 8, Table 6 ). The trend of fewer clams per bushel in area management options was muted by an increase in incidental mortality. Fewer simulations had significantly more clams per bushel under present-day management. The number of clams per bushel averaged $4 \%$ higher under present-day management than under the 7-year closure duration.

Landings per unit of effort All of the examined closure durations resulted in average increases of $8 \%$ in LPUE (Fig. 8, Table 6). The 3-year closure duration resulted in an increase in LPUE in an average of $64 \%$ of simulations (range: 56-89\%; Table 7) when compared with LPUE under present-day management. The 5-year closure duration showed significantly enhanced LPUE in an average of $56 \%$ of simulations and resulted in significant increases in LPUE in an average of $64 \%$ of simulations (range: 44-78\%; Table 7) when compared with LPUE under present-day management. The 7-year closure duration resulted in the least number of simulations having significantly increased LPUE (average: 42\%; range: $22-67 \%$; Table 7). The longest closure having the least amount of simulations with significantly improved LPUE might be attributed to the locations of closure. A closure based on the number of small clams per square meter might result in closure of some $10^{\prime}$ squares with the most total clams (i.e., small and market-size clams). As the closure duration increases, more $10^{\prime}$ squares are closed at a time. With the 7-year closure duration, more of the $10^{\prime}$ squares with high clam densities might be closed, thus causing a lower average LPUE.

Increased incidental mortality resulted in fewer simulations having significantly increased LPUE (Table 8). However, of the simulations where LPUE was significantly enhanced by alternative management, the 

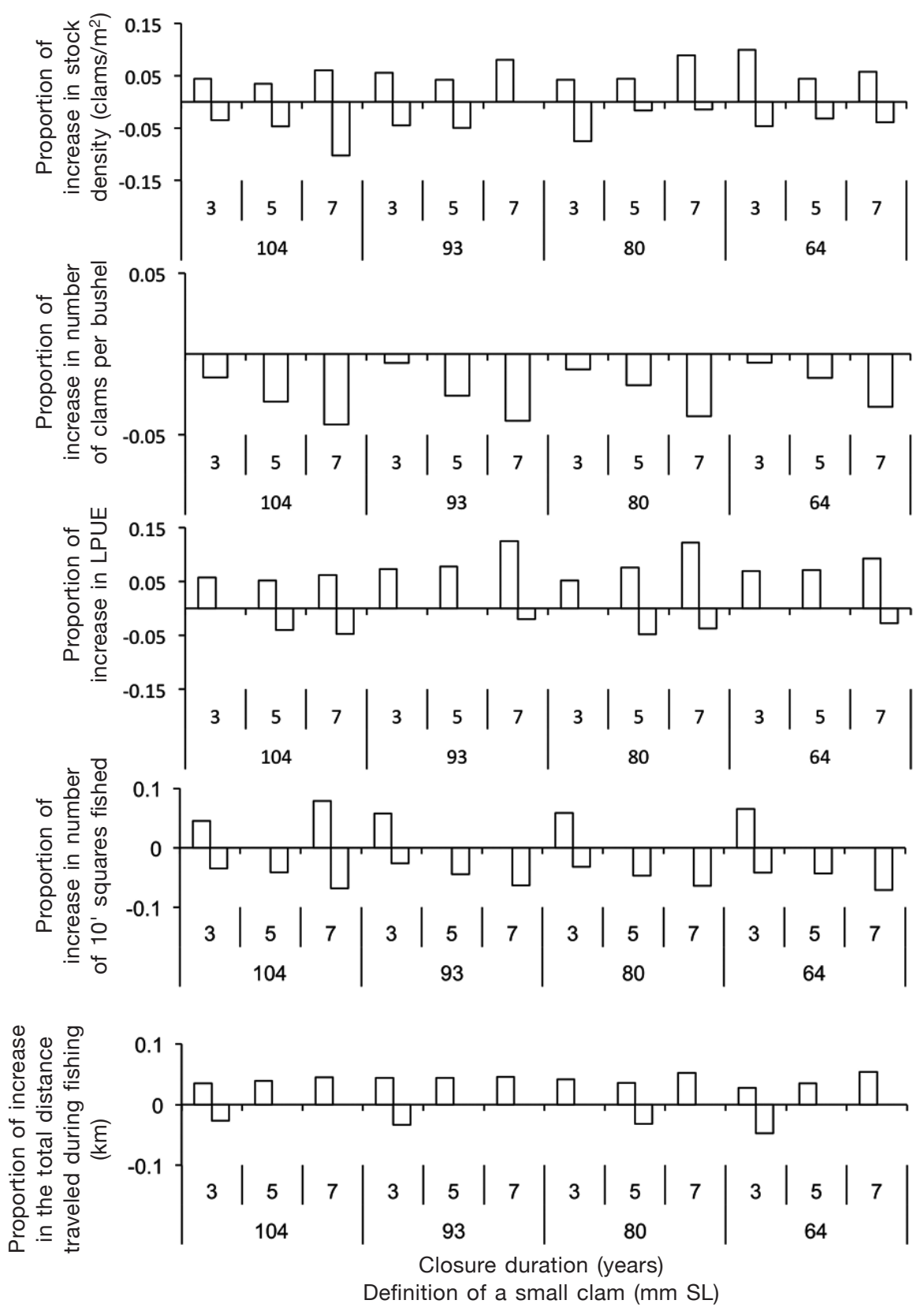

Figure 7

The proportion of change in performance metrics used to evaluate the effect of closure location rule 1 on the Atlantic surfclam (Spisula solidissima) population and commercial fishery in the Mid-Atlantic Bight. The effect is averaged for all simulations where a significant difference between present-day and alternative management exists (see Table 3 for the fraction of total simulations used to generate each bar value and Table 7 for summary statistics). Rule 1 mandates that the cell with the highest ratio of the number of small clams to the number of market-size clams be closed each year. Bars in the positive region represent proportional differences for simulations favoring alternative management. Proportional differences under present-day management represent simulations favoring present-day management and are represented as negative values for clarity. The metric of landings per unit of effort (LPUE) is the number of bushels per hour, and definitions of a small clam are given as shell length (SL) in millimeters. 
Table 4

Summary statistics for the average proportion of change (shown in Fig. 7) in performance metrics used to evaluate the effect of closure location rule 1 on the Atlantic surfclam (Spisula solidissima) population and on the commercial fishery in the Mid-Atlantic Bight. Rule 1 mandates that the cell with the highest ratio of the number of small clams to the number of market-size clams be closed each year. Size of clams is given as shell length (SL) in millimeters, closure duration is measured in years, and LPUE means landings per unit effort. $N$ is the number of simulations where a significant difference exists between the performance metric under present-day or alternative management at present-day abundance. The maximum $N$ is 9 .

\begin{tabular}{|c|c|c|c|c|c|c|c|c|c|c|c|c|c|}
\hline & & \multicolumn{12}{|c|}{ Definition of a small clam } \\
\hline & & \multicolumn{3}{|c|}{$104 \mathrm{~mm} \mathrm{SL}$} & \multicolumn{3}{|c|}{$93 \mathrm{~mm} \mathrm{SL}$} & \multicolumn{3}{|c|}{$80 \mathrm{~mm} \mathrm{SL}$} & \multicolumn{3}{|c|}{$64 \mathrm{~mm} \mathrm{SL}$} \\
\hline & & \multicolumn{12}{|c|}{ Closure duration (yr) } \\
\hline & & 3 & 5 & 7 & 3 & 5 & 7 & 3 & 5 & 7 & 3 & 5 & 7 \\
\hline \multicolumn{14}{|l|}{ Stock density } \\
\hline \multirow[t]{4}{*}{ Present management } & $N$ & 4 & 4 & 1 & 2 & 1 & 0 & 2 & 1 & 1 & 3 & 2 & 5 \\
\hline & $\chi^{2}$ & 0.04 & 0.05 & 0.10 & 0.04 & 0.05 & - & 0.08 & 0.02 & 0.01 & 0.05 & 0.03 & 0.04 \\
\hline & Min & 0.01 & 0.02 & - & 0.04 & - & - & 0.07 & - & - & 0.04 & 0.03 & 0.02 \\
\hline & Max & 0.08 & 0.08 & - & 0.05 & - & - & 0.08 & - & - & 0.05 & 0.04 & 0.06 \\
\hline \multirow[t]{4}{*}{ Alternative management } & $N$ & 4 & 3 & 6 & 3 & 6 & 4 & 5 & 5 & 4 & 2 & 3 & 3 \\
\hline & $\chi^{2}$ & 0.04 & 0.03 & 0.06 & 0.06 & 0.04 & 0.08 & 0.04 & 0.04 & 0.09 & 0.10 & 0.04 & 0.06 \\
\hline & Min & 0.02 & 0.02 & 0.04 & 0.03 & 0.02 & 0.03 & 0.02 & 0.02 & 0.04 & 0.03 & 0.03 & 0.05 \\
\hline & $\operatorname{Max}$ & 0.07 & 0.05 & 0.09 & 0.08 & 0.10 & 0.12 & 0.08 & 0.10 & 0.14 & 0.17 & 0.05 & 0.06 \\
\hline \multicolumn{14}{|l|}{ Number of clams per bushel } \\
\hline \multirow{4}{*}{ Present management } & $N$ & 5 & 9 & 9 & 2 & 9 & 9 & 2 & 9 & 9 & 2 & 9 & 9 \\
\hline & $\chi^{2}$ & 0.01 & 0.03 & 0.04 & 0.01 & 0.03 & 0.04 & 0.01 & 0.02 & 0.04 & 0.01 & 0.01 & 0.03 \\
\hline & Min & 0.01 & 0.02 & 0.03 & 0.01 & 0.02 & 0.03 & 0.01 & 0.01 & 0.03 & 0.01 & 0.01 & 0.02 \\
\hline & Max & 0.02 & 0.04 & 0.07 & 0.01 & 0.04 & 0.06 & 0.01 & 0.03 & 0.06 & 0.01 & 0.02 & 0.05 \\
\hline \multirow[t]{4}{*}{ Alternative management } & $N$ & 0 & 0 & 0 & 0 & 0 & 0 & 0 & 0 & 0 & 0 & 0 & 0 \\
\hline & $\chi^{2}$ & - & - & - & - & - & - & - & - & - & - & - & - \\
\hline & Min & - & - & - & - & - & - & - & - & - & - & - & - \\
\hline & Max & - & - & - & - & - & - & - & - & - & - & - & - \\
\hline \multicolumn{14}{|l|}{ LPUE } \\
\hline \multirow[t]{4}{*}{ Present management } & $N$ & 0 & 1 & 1 & 0 & 0 & 1 & 0 & 1 & 1 & 0 & 0 & 1 \\
\hline & $\chi^{2}$ & - & 0.04 & 0.05 & - & - & 0.02 & - & 0.05 & 0.04 & - & - & 0.02 \\
\hline & Min & - & - & - & - & - & - & - & - & - & - & - & - \\
\hline & Max & - & - & - & - & - & - & - & - & - & - & - & - \\
\hline \multirow[t]{4}{*}{ Alternative management } & $N$ & 4 & 3 & 5 & 6 & 7 & 4 & 7 & 7 & 3 & 5 & 8 & 4 \\
\hline & $\chi^{2}$ & 0.06 & 0.05 & 0.06 & 0.07 & 0.08 & 0.12 & 0.05 & 0.08 & 0.12 & 0.07 & 0.07 & 0.09 \\
\hline & Min & 0.02 & 0.04 & 0.04 & 0.04 & 0.03 & 0.06 & 0.02 & 0.05 & 0.09 & 0.02 & 0.02 & 0.06 \\
\hline & Max & 0.07 & 0.06 & 0.10 & 0.20 & 0.16 & 0.21 & 0.14 & 0.13 & 0.17 & 0.18 & 0.11 & 0.15 \\
\hline \multicolumn{14}{|l|}{ Number of $10^{\prime}$ squares fished } \\
\hline \multirow[t]{4}{*}{ Present management } & $N$ & 4 & 5 & 6 & 3 & 4 & 5 & 4 & 5 & 4 & 4 & 4 & 5 \\
\hline & $\chi^{2}$ & 0.03 & 0.04 & 0.07 & 0.03 & 0.04 & 0.06 & 0.03 & 0.05 & 0.06 & 0.04 & 0.04 & 0.07 \\
\hline & Min & 0.02 & 0.02 & 0.05 & 0.02 & 0.04 & 0.05 & 0.02 & 0.02 & 0.03 & 0.02 & 0.04 & 0.05 \\
\hline & $\operatorname{Max}$ & 0.05 & 0.06 & 0.09 & 0.03 & 0.05 & 0.08 & 0.04 & 0.08 & 0.09 & 0.10 & 0.05 & 0.10 \\
\hline \multirow[t]{4}{*}{ Alternative management } & $N$ & 2 & 0 & 1 & 1 & 0 & 0 & 1 & 0 & 0 & 3 & 0 & 0 \\
\hline & $\chi^{2}$ & 0.04 & - & 0.08 & 0.06 & - & - & 0.06 & - & - & 0.07 & - & - \\
\hline & Min & 0.04 & - & - & - & - & - & - & - & - & 0.05 & - & - \\
\hline & Max & 0.06 & - & - & - & - & - & - & - & - & 0.09 & - & - \\
\hline Total distance traveled & & & & & & & & & & & & & \\
\hline Present management & $N$ & 1 & 0 & 0 & 1 & 0 & 0 & 0 & 1 & 0 & 1 & 0 & 0 \\
\hline & $\chi^{2}$ & 0.03 & - & - & 0.03 & - & - & - & 0.03 & - & 0.05 & - & - \\
\hline & Min & - & - & - & - & - & - & - & - & - & - & - & - \\
\hline & Max & - & - & - & - & - & - & - & - & - & - & - & - \\
\hline Alternative management & $N$ & 3 & 5 & 7 & 1 & 4 & 6 & 3 & 4 & 4 & 2 & 4 & 4 \\
\hline & $\chi^{2}$ & 0.03 & 0.04 & 0.04 & 0.04 & 0.04 & 0.05 & 0.04 & 0.04 & 0.05 & 0.03 & 0.03 & 0.05 \\
\hline & Min & 0.03 & 0.03 & 0.03 & - & 0.02 & 0.02 & 0.04 & 0.02 & 0.03 & 0.02 & 0.02 & 0.03 \\
\hline & Max & 0.04 & 0.05 & 0.07 & - & 0.07 & 0.06 & 0.05 & 0.04 & 0.08 & 0.03 & 0.05 & 0.08 \\
\hline
\end{tabular}


Table 5

Evaluation of the model simulations in which closure location rule 1 was used to examine the influence of increased incidental mortality on the stock and commercial fishery of Atlantic surfclam (Spisula solidissima) in the Mid-Atlantic Bight. Tabulated are the proportion of simulations where metrics used to evaluate the Atlantic surfclam population and the effect of area management on the commercial industry were significantly greater under alternative management with $0 \%$ or $20 \%$ incidental mortality with present-day abundance. Rule 1 mandates that the cell with the highest ratio of the number of small clams to the number of market-size clams is closed each year. Number of clams per bushel is not included because present-day management always has higher numbers of clams per bushel. There were 9 simulations per percentage. Any fraction over 0.11 ( 1 significant difference out of 9 ) is unlikely to occur by chance (exact binomial test: $\alpha=0.05$; Conover, 1980). Size of clams is given as shell length (SL) in millimeters, closure duration is measured in years, and LPUE means landings per unit of effort.

\begin{tabular}{|c|c|c|c|c|c|c|c|c|c|c|c|c|}
\hline & \multicolumn{12}{|c|}{ Definition of a small clam } \\
\hline & \multicolumn{3}{|c|}{104 mm SL } & \multicolumn{3}{|c|}{$93 \mathrm{~mm} \mathrm{SL}$} & \multicolumn{3}{|c|}{$80 \mathrm{~mm} \mathrm{SL}$} & \multicolumn{3}{|c|}{$64 \mathrm{~mm} \mathrm{SL}$} \\
\hline & \multicolumn{12}{|c|}{ Closure duration (yr) } \\
\hline & 3 & 5 & 7 & 3 & 5 & 7 & 3 & 5 & 7 & 3 & 5 & 7 \\
\hline \multicolumn{13}{|l|}{ Stock density } \\
\hline $0 \%$ incidental mortality & 0.44 & 0.33 & 0.56 & 0.44 & 0.67 & 0.44 & 0.56 & 0.56 & 0.44 & 0.22 & 0.33 & 0.33 \\
\hline $20 \%$ incidental mortality & 0.56 & 0.78 & 0.78 & 0.44 & 0.78 & 0.78 & 0.22 & 0.56 & 0.67 & 0.22 & 0.56 & 0.56 \\
\hline \multicolumn{13}{|l|}{ LPUE } \\
\hline $0 \%$ incidental mortality & 0.44 & 0.33 & 0.56 & 0.67 & 0.56 & 0.44 & 0.78 & 0.78 & 0.33 & 0.56 & 0.89 & 0.44 \\
\hline $20 \%$ incidental mortality & 0.67 & 0.78 & 0.56 & 0.67 & 0.89 & 0.78 & 0.44 & 0.67 & 0.56 & 0.22 & 0.67 & 0.78 \\
\hline \multicolumn{13}{|l|}{ Number of $10^{\prime}$ squares fished } \\
\hline $0 \%$ incidental mortality & 0.22 & 0.00 & 0.11 & 0.11 & 0.00 & 0.00 & 0.11 & 0.00 & 0.00 & 0.33 & 0.00 & 0.00 \\
\hline $20 \%$ incidental mortality & 0.22 & 0.00 & 0.11 & 0.00 & 0.00 & 0.11 & 0.11 & 0.11 & 0.11 & 0.11 & 0.00 & 0.00 \\
\hline \multicolumn{13}{|l|}{ Total distance traveled } \\
\hline $0 \%$ incidental mortality & 0.33 & 0.56 & 0.78 & 0.11 & 0.44 & 0.67 & 0.33 & 0.44 & 0.44 & 0.22 & 0.44 & 0.44 \\
\hline $20 \%$ incidental mortality & 0.11 & 0.33 & 0.56 & 0.56 & 0.22 & 0.44 & 0.33 & 0.44 & 0.44 & 0.33 & 0.22 & 0.44 \\
\hline
\end{tabular}

average proportion of increase in LPUE was improved. The 5-year closure duration showed the most improvement with LPUE increased by an average of $12 \%$ (compared with $8 \%$ without additional mortality).

Number of $10^{\prime}$ squares fished As the duration of a closure increased, the percentage of simulations with significantly more $10^{\prime}$ squares fished during the year decreased. The average percentage of increase in $10^{\prime}$ squares fished under present-day management and over all alternative management strategies was only $3 \%$ and $4 \%$ respectively, however (Fig. 8 , Table 6 ). The high percentage of simulations that showed no significant difference between present-day and any closure duration $(66 \%, 75 \%$, and $59 \%$ for the 3-, 5-, and 7 -year closure durations; Table 7), accompanied by the small percent changes, indicate little effect of any alternative management strategy in changing the number of $10^{\prime}$ squares visited during fishing. As incidental mortality increased, slightly fewer $10^{\prime}$ are visited with increasing closure duration (Table 8). The percentage of cases where significantly fewer $10^{\prime}$ squares were visited under alternative management increased; however, the average percentage of increases of $10^{\prime}$ squares visited under present-day or alternative management were still $5 \%$ or less (Fig. 8, Table 6).
Distance traveled per fishing trip The distance traveled per fishing trip increased significantly in $94 \%$ of simulations for the 3-year closure duration and in $90 \%$ of simulations for the 5- and 7-year closure durations (Table 7). The average percent increase for each of the closure durations was only 5\%, however (Fig. 8, Table 6). An increase in incidental mortality resulted in a lower percentage of simulations with increased distance traveled during fishing trips (averages of $41 \%, 61 \%$, and $64 \%$ for the 3-, 5-, and 7-year closure durations; Table 8 ). The percentage of increase was less than $4 \%$ for all closure durations.

\section{Discussion}

\section{Perspective}

The goal of this study was to use an MSE to investigate possible options that could enhance productivity in the Atlantic surfclam stock without unjustifiably limiting the fishery through undesirable economic impacts. An MSE allows an evaluation of alternative management options on the basis of performance metrics that are understood by and valuable to both stakeholders and fishery managers. The range contraction of Atlantic 

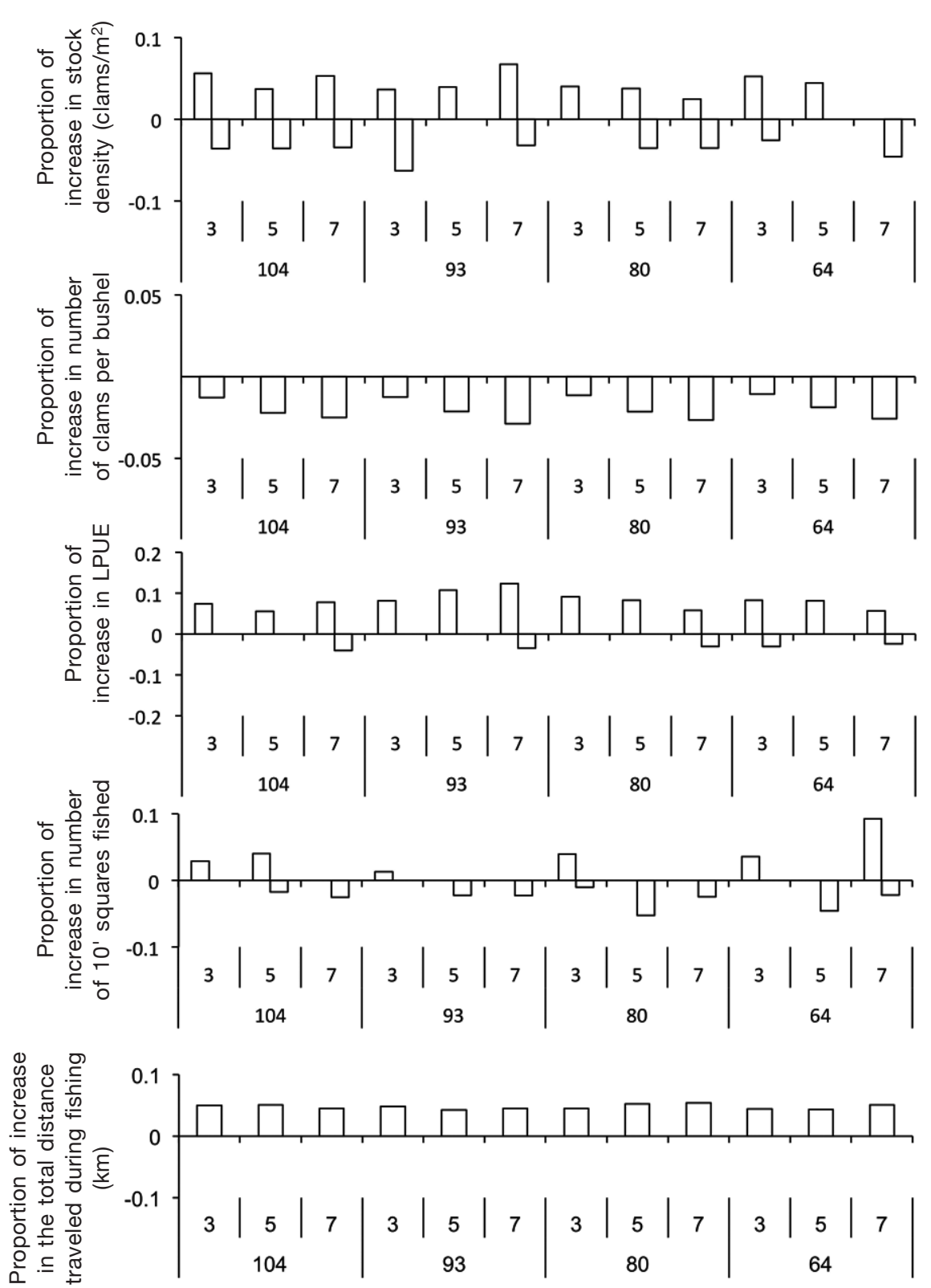

Closure duration (years)

Definition of a small clam ( $\mathrm{mm} \mathrm{SL}$ )

Figure 8

The proportion of change in performance metrics used to evaluate the effect of closure location rule 2 on the Atlantic surfclam (Spisula solidissima) population and commercial fishery in the Mid-Atlantic Bight averaged for all simulations where a significant difference between present-day and alternative management exists (see Table 6 for the fraction of total simulations used to generate each bar value and Table 8 for summary statistics). Rule 2 mandates that the cell with the highest density of small clams (number of clams per square meter) be closed each year. Bars in the positive region represent proportional differences under alternative management. Proportional differences under present-day management are represented in negative values for clarity. The metric of landings per unit of effort (LPUE) is the number of bushels per hour, and definitions of a small clam are given as shell length (SL) in millimeters. 
Table 6

Summary statistics for average proportion of change (shown in Fig. 8) in performance metrics used to evaluate the effect of closure location rule 2 on the Atlantic surfclam (Spisula solidissima) population and commercial fishery. Size of clams is given as shell length (SL) in millimeters, closure duration is measured in years, and LPUE means landings per unit of effort. $N$ is the number of simulations where a significant difference exists between the performance metric using present-day or alternative management at present-day abundance. The maximum $N$ is 9 .

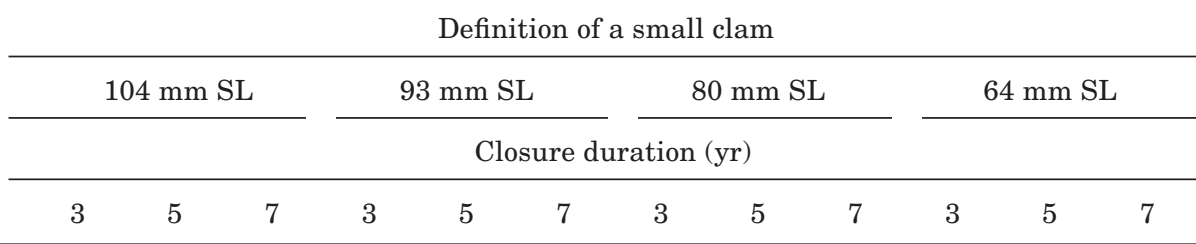

Stock density

Present management

\section{$N$}

$$
\begin{aligned}
& N \\
& \chi^{2} \\
& \text { Min }
\end{aligned}
$$

Alternative management$$
\chi^{2}
$$

Number of clams per bushel

Present management

Alternative management

LPUE

Present management

Alternative management

Number of $10^{\prime}$ squares fished

Present management

Total distance traveled

Present management

Alternative management

Alternative management

$$
\begin{aligned}
& \chi^{2} \\
& \text { Min } \\
& \text { Max }
\end{aligned}
$$

Min

$\operatorname{Max}$

$N$
$\chi^{2}$

$\chi^{2}$

Min$$
\begin{aligned}
& N \\
& \chi^{2}
\end{aligned}
$$$$
\chi^{2}
$$$$
\text { Max }
$$

$N$

$\chi^{2}$

Min$$
\begin{gathered}
3 \\
0.04 \\
0.03 \\
0.04 \\
3 \\
0.06 \\
0.04 \\
0.07 \\
\\
6 \\
0.01 \\
0.01 \\
0.02 \\
0 \\
- \\
- \\
-
\end{gathered}
$$

3

\section{1}

$$
0.03
$$

3

0.06

0.04

0.07

0.01

0.01
0.02

0

$N$
$\chi^{2}$

$\chi^{2}$

Max

N

$\chi^{2}$

Min

Max

$N$
$\chi^{2}$

Min

Max

$N$
$\chi^{2}$

Min

$\operatorname{Max}$

N

$\chi^{2}$

Min

Max

$\chi^{2}$$$
\text { - }
$$$$
5
$$$$
5
$$$$
\begin{array}{ll}
0.07 & 0.06
\end{array}
$$$$
\begin{array}{ll}
0.02 & 0.04
\end{array}
$$$$
\begin{array}{ll}
0.16 & 0.09
\end{array}
$$

3

0.03

0.01

2
0.04

0.06

0.01

0$$
\text { - }
$$$$
9
$$

$$
0.05
$$$$
0.03
$$$$
\begin{array}{ccc}
0 & 0 & 1 \\
- & - & 0.04
\end{array}
$$$$
0.04
$$$$
-
$$$$
\begin{aligned}
& 0 \\
& - \\
& -
\end{aligned}
$$$$
0
$$$$
\begin{array}{cc}
0 & 1 \\
- & 0.03 \\
- & -
\end{array}
$$

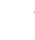$$
\begin{gathered}
4 \\
0.08
\end{gathered}
$$

0.08
0.03

0.19

5
0.08

0.08
0.04

0.14

$\begin{array}{ccc}0 & 1 & 4 \\ - & 0.02 & 0.03 \\ - & - & 0.01\end{array}$

$\begin{array}{lll}- & - & 0.01 \\ - & - & 0.08\end{array}$

0

$0.07 \quad 0.07$

$-$

4

0.10

0.05

0.20

3
0.12

0.12
0.07

0.07
0.21

$0.21 \quad 0.20$

2
0.03
0.02
0.05
4
0.07
0.04
0.11

0

$-$

$-$

$-$

.04

01

06

1
0.04
-
-
6
0.04
0.01
0.07

1
0.04

3

0.03

- 0.01

- 0.04

5

0.02

$0.01 \quad 0.02$

$0.04 \quad 0.09$

6

9

$\begin{array}{llll}9 & 3 & 8 & 9\end{array}$

$0.02 \quad 0.03$

0.01

0.01

0.02

0.01

0.03

0.01
0.05

0.01

0.01

$0.01 \quad 0.01$

$\begin{array}{llllll}0.02 & 0.04 & 0.05 & 0.02 & 0.04 & 0.05\end{array}$

$$
\begin{array}{ll} 
& \\
\hline .09 & 0.08 \\
03 & 0.04 \\
.0 & 0 .
\end{array}
$$

$$
\begin{gathered}
0 \\
- \\
- \\
- \\
6 \\
0.08 \\
0.04 \\
0.18
\end{gathered}
$$

1

$0.03 \quad 0.03$

$-$

$-$

0.06

0.02

0.09

5
0.08

0.03

0.20

$$
\begin{array}{cc}
0 & 1 \\
- & 0.02 \\
- & - \\
- & - \\
7 & 2 \\
0.08 & 0.06 \\
0.03 & 0.03 \\
0.20 & 0.08
\end{array}
$$

$$
\begin{array}{cccccccc}
1 & 2 & 1 & 2 & 4 & 0 & 3 & 4 \\
0.02 & 0.02 & 0.01 & 0.05 & 0.02 & - & 0.05 & 0.02 \\
- & 0.01 & - & 0.02 & 0.01 & - & 0.02 & 0.01 \\
- & 0.04 & - & 0.08 & 0.04 & - & 0.07 & 0.04 \\
0 & 0 & 2 & 0 & 0 & 2 & 0 & 0 \\
- & - & 0.04 & - & - & 0.04 & - & - \\
- & - & 0.01 & - & - & 0.01 & - & - \\
- & - & 0.07 & - & - & 0.06 & - & -
\end{array}
$$




\section{Table 7}

Evaluation of model simulations in which closure location rule 2 was used to examine the influence of area management on the Atlantic surfclam (Spisula solidissima) stock and commercial fishery in the Mid-Atlantic Bight. Tabulated are the proportion of simulations where metrics used to evaluate the Atlantic surfclam population and commercial fishery were significantly greater under present-day or alternative management with closure location rule 2 with present-day abundance. Rule 2 mandates that the cell with the highest density of small clams (number of clams per square meter) be closed each year. There were 9 simulations per percentage. Any fraction over 0.11 ( 1 significant difference out of 9 ) is unlikely to occur by chance (exact binomial test: $\alpha=0.05$; Conover, 1980). Size of clams is given as shell length (SL) in millimeters, closure duration is measured in years, and LPUE means landings per unit of effort.

\begin{tabular}{|c|c|c|c|c|c|c|c|c|c|c|c|c|}
\hline & \multicolumn{12}{|c|}{ Definition of a small clam } \\
\hline & \multicolumn{3}{|c|}{$104 \mathrm{~mm} \mathrm{SL}$} & \multicolumn{3}{|c|}{$93 \mathrm{~mm} \mathrm{SL}$} & \multicolumn{3}{|c|}{$80 \mathrm{~mm} \mathrm{SL}$} & \multicolumn{3}{|c|}{$64 \mathrm{~mm} \mathrm{SL}$} \\
\hline & \multicolumn{12}{|c|}{ Closure duration (yr) } \\
\hline & 3 & 5 & 7 & 3 & 5 & 7 & 3 & 5 & 7 & 3 & 5 & 7 \\
\hline \multicolumn{13}{|l|}{ Stock density } \\
\hline Present management & 0.33 & 0.11 & 0.11 & 0.22 & 0.00 & 0.22 & 0.00 & 0.11 & 0.11 & 0.33 & 0.00 & 0.11 \\
\hline Alternative management & 0.33 & 0.44 & 0.56 & 0.44 & 0.33 & 0.44 & 0.44 & 0.67 & 0.56 & 0.22 & 0.56 & 0.00 \\
\hline \multicolumn{13}{|l|}{ Number of clams per bushel } \\
\hline Present management & 0.67 & 0.89 & 0.89 & 0.78 & 0.89 & 1.00 & 0.67 & 1.00 & 1.00 & 0.33 & 0.89 & 1.00 \\
\hline Alternative management & 0.00 & 0.00 & 0.00 & 0.00 & 0.00 & 0.00 & 0.00 & 0.00 & 0.00 & 0.00 & 0.00 & 0.00 \\
\hline \multicolumn{13}{|l|}{ LPUE } \\
\hline Present management & 0.00 & 0.11 & 0.11 & 0.00 & 0.00 & 0.11 & 0.00 & 0.00 & 0.11 & 0.11 & 0.00 & 0.22 \\
\hline Alternative management & 0.56 & 0.67 & 0.44 & 0.56 & 0.44 & 0.33 & 0.89 & 0.67 & 0.67 & 0.56 & 0.78 & 0.22 \\
\hline \multicolumn{13}{|l|}{ Number of $10^{\prime}$ squares fished } \\
\hline Present management & 0.00 & 0.11 & 0.44 & 0.00 & 0.11 & 0.22 & 0.11 & 0.22 & 0.44 & 0.00 & 0.33 & 0.44 \\
\hline Alternative management & 0.67 & 0.22 & 0.00 & 0.11 & 0.00 & 0.00 & 0.22 & 0.00 & 0.00 & 0.22 & 0.00 & 0.11 \\
\hline \multicolumn{13}{|l|}{ Total distance traveled } \\
\hline Present management & 0.00 & 0.00 & 0.00 & 0.00 & 0.00 & 0.00 & 0.00 & 0.00 & 0.00 & 0.00 & 0.00 & 0.00 \\
\hline Alternative management & 1.00 & 1.00 & 0.89 & 1.00 & 0.89 & 0.78 & 0.89 & 0.89 & 0.89 & 0.89 & 0.78 & 1.00 \\
\hline
\end{tabular}

surfclam as a result of increasing bottom water temperatures in the MAB is understood by both groups and has implications not only for the Atlantic surfclam population itself but also for the commercial fishery supported by the clam stock in this area. The commercial fishery, which historically extended as far south as northern Virginia in the MAB, is now concentrated off the New Jersey shore (Cargnelli et al., 1999; Jacobson and Weinberg ${ }^{1}$; NEFSC ${ }^{2}$ ). The ongoing increase in fishing pressure in this region, as a consequence of the range contraction, is already manifesting itself as a reduced LPUE and an increasing inability to catch the allocated quota. Local overfishing is likely to occur as consolidation of fishing pressure in this area increases. Barring modifications to the present-day management plan or transfer of additional effort northeast to southern New England and Georges Bank, LPUE will likely continue to decline. Because of the location of processing plants, such a transfer of effort would be extremely expensive and therefore represents an economically implausible option. The present-day management plan offers no responsive option. The need to improve the condition of the stock while allowing continued support of the historical fishery is a major challenge.

Area management, such as temporary or permanent closures (Walters, 2000; Bloomfield et al., 2012; Córdo-
va-Lepe et al., 2012), has proven to be a useful tool to improve shellfish fisheries. The inclusion of fishermen's behavior in area management is essential because the response of the fishery to management measures is critical in the evaluation of preferred and realistic options (Hilborn, 1992; Gillis et al., 1995; Millischer and Gascuel, 2006; Link et al., 2011). Although this MSE model (SEFES) captures the essential components of a highly variable system (i.e., the Atlantic surfclam population and fishery), some assumptions are required. The lack of knowledge about incidental Atlantic surfclam mortality as a result of dredging procedures requires an assumption concerning the degree of its importance. Fishing gear also can generate incidental shell damage (Witbaard and Klein, 1994; Gilkinson et al., 2005; Vasconcelos et al., 2011) that, in the case of bivalves, may not be easily repaired (Alexander and Dietl, 2001; Moschino et al., 2003). Consequently, simulations were conducted for $0 \%$ and $20 \%$ incidental mortality of the clams encountered but not retained by the dredge with the upper value chosen from limited a priori data. Another source of uncertainty is determining the annual number and distribution of recruits across the Atlantic surfclam population. In order to account for the mean annual number and distribution of recruits, simulations included a range of degrees of patchiness in re- 


\section{Table 8}

Evaluation of model simulations in which closure location rule 2 was used to examine the influence of increased incidental mortality on the Atlantic surfclam (Spisula solidissima) stock and commercial fishery in the Mid-Atlantic Bight. Tabulated are the proportion of simulations where metrics used to evaluate the Atlantic surfclam population and the effect of area management on the commercial industry were significantly greater under alternative management with $0 \%$ or $20 \%$ incidental mortality using closure location rule 2 with present-day abundance. Rule 2 mandates that the cell with the highest density of small clams (number of clams per square meter) be closed each year. Number of clams per bushel is not included because present-day management always has higher numbers of clams per bushel. There were 9 simulations per percentage. Any fraction over 0.11 ( 1 significant difference out of 9) is unlikely to occur by chance (exact binomial test: $\alpha=0.05$; Conover, 1980). Size of clams is given as shell length (SL) in millimeters, closure duration is measured in years, and LPUE means landings per unit of effort.

\begin{tabular}{|c|c|c|c|c|c|c|c|c|c|c|c|c|}
\hline & \multicolumn{12}{|c|}{ Definition of a small clam } \\
\hline & \multicolumn{3}{|c|}{104 mm SL } & \multicolumn{3}{|c|}{$93 \mathrm{~mm} \mathrm{SL}$} & \multicolumn{3}{|c|}{$80 \mathrm{~mm} \mathrm{SL}$} & \multicolumn{3}{|c|}{$64 \mathrm{~mm} \mathrm{SL}$} \\
\hline & \multicolumn{12}{|c|}{ Closure duration (yr) } \\
\hline & 3 & 5 & 7 & 3 & 5 & 7 & 3 & 5 & 7 & 3 & 5 & 7 \\
\hline \multicolumn{13}{|l|}{ Stock density } \\
\hline $0 \%$ incidental mortality & 0.33 & 0.44 & 0.56 & 0.44 & 0.33 & 0.44 & 0.44 & 0.67 & 0.56 & 0.22 & 0.56 & 0.00 \\
\hline $20 \%$ incidental mortality & 0.22 & 0.33 & 0.44 & 0.56 & 0.22 & 0.44 & 0.44 & 0.56 & 0.56 & 0.22 & 0.44 & 0.22 \\
\hline \multicolumn{13}{|l|}{ LPUE } \\
\hline $0 \%$ incidental mortality & 0.56 & 0.67 & 0.44 & 0.56 & 0.44 & 0.33 & 0.89 & 0.67 & 0.67 & 0.56 & 0.78 & 0.22 \\
\hline $20 \%$ incidental mortality & 0.44 & 0.44 & 0.33 & 0.67 & 0.22 & 0.44 & 0.67 & 0.67 & 0.56 & 0.33 & 0.56 & 0.44 \\
\hline \multicolumn{13}{|l|}{ Number of $10^{\prime}$ squares fished } \\
\hline $0 \%$ incidental mortality & 0.67 & 0.22 & 0.00 & 0.11 & 0.00 & 0.00 & 0.22 & 0.00 & 0.00 & 0.22 & 0.00 & 0.11 \\
\hline $20 \%$ incidental mortality & 0.22 & 0.00 & 0.00 & 0.11 & 0.00 & 0.00 & 0.22 & 0.00 & 0.00 & 0.11 & 0.11 & 0.00 \\
\hline \multicolumn{13}{|l|}{ Total distance traveled } \\
\hline $0 \%$ incidental mortality & 1.00 & 1.00 & 0.89 & 1.00 & 0.89 & 0.78 & 0.89 & 0.89 & 0.89 & 0.89 & 0.78 & 1.00 \\
\hline $20 \%$ incidental mortality & 0.44 & 0.67 & 0.67 & 0.33 & 0.67 & 0.56 & 0.22 & 0.56 & 0.67 & 0.67 & 0.56 & 0.67 \\
\hline
\end{tabular}

cruitment. A net downcoast drift of larvae previously identified in larval dispersion studies was not included because postsettlement mortality appears to have a much larger effect on patchiness (Zhang et al., 2015, 2016): postsettlement mortality was incorporated into the model as patchy recruitment. Additional assumptions were made regarding the influence of climate change on the stock and commercial fishery over the simulated timespan of fishing years used to compare performance metrics (76 years). Climate change will likely continue over the next 76 years (Scavia et al., 2002; Feely et al., 2009); it follows that changes in the population dynamics and range of the Atlantic surfclam also will occur (e.g., Munroe et al., 2016). The extent to which climate change will influence the Atlantic surfclam stock is impossible to assess; therefore, the set of simulations used in this study does not include anticipated future conditions. Even if the geographic range of clams was to change over the coming 76 years, the outcomes of area management discussed here rely primarily on a constant ambit of physiological responses by the Atlantic surfclam within its habitable range and on the recognition that the Atlantic surfclam fishery has a limited ambit to adapt to changes in Atlantic surfclam density, whether that density increases or declines (Powell et al., 2016). Additionally, realistically predicting the improvement in vessel technology and its influence on a captain's skill and vessel economics is totally speculative. It may be assumed that developments will occur that increase vessel and harvest efficiency (i.e., become more fuel efficient, provide improved onboard refrigeration); however, unlike the gear of many fisheries, the efficiency of hydraulic dredges is already near $80 \%$ on good fishing grounds, so that substantial improvements in catch efficiency are unlikely. The extent to which these developments will affect the stock and commercial industry over a 76-year time span is unquantifiable, but such changes are unlikely to drastically change the outcome of area management as simulated in this study, because these outcomes are primarily influenced by varying fishing pressure across the stock under a defined FMP quota cap. The area management options presented in this study could be implemented long before major changes in the fleet configuration could take place. For this reason, changes in boat characteristics and the skill of captains are held constant over the 76-year period of simulation.

\section{Influence of area management on Atlantic surfclam stock}

Performance metrics used to evaluate the influence of area management on the MAB Atlantic surfclam stock 


\section{Table 9}

Summary of alternative management strategies for determining the management option that offers benefits to both the stock and commercial fishery of the Atlantic surfclam (Spisula solidissima) in the Mid-Atlantic Bight. Plus signs indicate the management strategy (either present-day or area management through closures) that resulted in the highest values of performance metrics. In situations where equivalent proportions of simulations resulted in increases, a plus sign is given to both strategies (i.e., landings per unit of effort).

\begin{tabular}{lccc}
\hline & $\begin{array}{c}\text { Rule } 1 \\
\text { Present-day } \\
\text { management }\end{array}$ & $\begin{array}{c}\text { Rule } 2 \\
\text { (ratio of the number } \\
\text { of small clams to } \\
\text { market-size clams) }\end{array}$ & $\begin{array}{c}\text { (number of small } \\
\left.\text { clams } / \mathrm{m}^{2}\right)\end{array}$ \\
\hline $\begin{array}{l}\text { Stock density (number of clams/m2) } \\
\text { Number of clams per bushel }\end{array}$ & + & + & + \\
$\begin{array}{l}\text { Landings per unit of effort (bushels/h) } \\
\text { Number of 10' squares fished } \\
\text { Total distance traveled (km) }\end{array}$ & + & + & + \\
\hline
\end{tabular}

are 1) the whole-stock density of clams recruited to the fishery (i.e., clams $\geq 120 \mathrm{~mm}$ SL), and the 2) number of clams per bushel. Simulations suggest that implementation of closure location rule 1 offers greater improvement to the stock, as measured by an increase in whole-stock density or a decrease in the number of clams per bushel due to an increase in clam size, in comparison with implementation of closure location rule 2 (Table 9 ). That is, closing a $10^{\prime}$ square on the basis of the proportional abundance of small clams offers improved outcomes in comparison with the same choice that is based on the density of small clams. The stock density showed a $4-7 \%$ increase under closure location rule 1 . To put these values in perspective, the increase is more than double the fraction of the stock removed by the fishery in a given year over the entire stock and is very near the exploitation rate for the area of highest exploitation, offshore New Jersey.

Tracking the number of clams per bushel also is one way to evaluate the status of the stock. A thriving stock will have larger clams and consequently the fishery will require fewer clams to fill a bushel. That is, landing larger clams results in fewer individuals being removed from the population under a specified quota, thus conserving stock density. One of the critical characteristics of the Atlantic surfclam fishery is that fishing economics and fishery management are specified in terms of volume, whereas the stock itself is best defined in terms of number of individuals. The number of clams per bushel is significantly lower under area management in an average $31 \%$ of 3 -year closure duration simulations and $100 \%$ of the 5- and 7-year closure duration simulations, regardless of the definition of a small clam. An increase of $4 \%$ in the number of clams required to fill a bushel under present-day management equates to an excess of about 3 clams per bushel when compared with alternative management. Three fewer clams per bushel translates to around 1 less bushel being required to fill a cage (32 bushels=1 cage). Annu- ally, the equivalent of approximately 4557 cages would therefore remain in the fishable stock because these animals would not be needed to fill the quota during fishing trips. About 81 extra trips of a boat capable of carrying 56 cages would be supported. Alternatively, these clams increase whole-stock density.

\section{Influence of area management on the commercial fishery}

Performance metrics used to evaluate the influence of area management on the Atlantic surfclam fishery are LPUE, the number of $10^{\prime}$ squares visited yearly, and the total distance traveled by the fishing vessel. Closure location rule 1 results in greater opportunities for the commercial fishery (Table 9). LPUE is increased significantly over all definitions of a small clam in an average of $61 \%, 64 \%$, and $44 \%$ of simulations for the 3-, 5-, and 7-year closures respectively (Table 3). The greatest percent increase in LPUE under closure location rule 1 produced enough time saved at sea to enable transit for an additional $16.7 \mathrm{~km}$ (9 nautical miles), or the addition of one $10^{\prime}$ square in any direction from the port, increasing the fishable area under the dock-todock time constraint imposed by the rate of spoilage of clams on deck. With an increase in incidental mortality, the extra time saved by an increase of $15 \%$ in LPUE would allow the boats to travel to 2 additional 10' squares in the same amount of time (approximately 36 $\mathrm{h}$ from the start of fishing to the landing of the clams during the warmer months of the year). A $6 \%$ increase in LPUE would result in a boat that is capable of carrying 56 cages filling all cages about $2 \mathrm{~h}$ faster per trip, thus permitting more transit time to fish farther from home port-37.0 km (20 nautical miles) for most vessels steaming at $5 \mathrm{~m} / \mathrm{s}(10 \mathrm{kn})$, under the 36 -h time constraint. A $15 \%$ increase in LPUE would equate to a reduction of $5 \mathrm{~h}$ of fishing time per trip. As fuel use is highest while fishing (both the main engine and water pump are running), any increase in LPUE exerts an 
important economic gain in reducing the cost of fuel relative to the value of the landed clams.

The number of $10^{\prime}$ squares visited during fishing increases significantly in an average of $7 \%$ of simulations over all closure durations and definitions of a small clam in comparison with an average of $49 \%$ of simulations under present-day management. A reduction in the number of $10^{\prime}$ squares visited suggests that captains (who choose a fishing location on the basis of highest catch rate, but who are limited in the summer by the 36 -h time constraint) target the recently opened $10^{\prime}$ squares. The distance traveled during fishing also increases significantly in up to $58 \%$ of simulations. An increase in distance traveled occurs in some cases because the closed $10^{\prime}$ squares are close to the home ports and require that captains steam farther away from port to fish. In addition, some of the $10^{\prime}$ squares recently opened are farther from home port, but the higher LPUE makes travel to them economically advantageous. Reduced distance is often preferred because reduced steaming time reduces operational costs, thus increasing profit margins, unless the additional cost of steaming is compensated by a reduction in other trip costs. This would be the case if LPUE also increases, as it does in these simulations. If a vessel steams for $8 \mathrm{~h}$ at a speed of $5 \mathrm{~m} / \mathrm{s}$, a $4 \%$ increase in distance traveled would result in approximately an additional $7.4 \mathrm{~km}$ (4 nautical miles), which would allow fishing of 1 additional 10' square away from home port without substantial additional costs if that $10^{\prime}$ square yielded a higher LPUE.

\section{Influence of control rules}

The criterion used to select a closure location is important for the success of management in offering enhanced stock densities and additional economic opportunity to the industry. Two closure location rules were investigated that represent end-members [extreme options] of a range of choices for a control rule; one places importance on the number of small clams in relation to the number of market-size clams (rule 1) and the other places importance on the density of small clams in an area (rule 2). Optimizing area management would require evaluation of the influence of combined rules, such as the $10^{\prime}$ square with the highest density of small clams among the $25 \%$ of $10^{\prime}$ squares with the highest proportion of small clams. A comparison of the end-member options, however, shows that stock density increased in a higher percentage of simulations under closure location rule 1 , the proportional rule, in comparison with closure location rule 2 and present-day management. Average percent increases in stock density are also higher under closure location rule 1. Accordingly, an increase in stock density is seen when the $10^{\prime}$ square with the greatest number of small clams in comparison with the number of market-size clams is closed to fishing for some duration of years. Both closure location rules resulted in an average of $64 \%$ of simulations having increased LPUE when compared with present- day management (i.e., no closures). A higher average percentage of increase resulted with closure location rule 2. However, closure location rule 1 resulted in an increase in LPUE as the closure duration increased, as opposed to a gradual decline seen when using closure location rule 2. An increase in LPUE when high importance is placed on the presence of small clams suggests that protecting small clams is a key factor in offering more economic opportunity to the fishing industry.

When the choice of closure location is based on the ratio of the number of small clams to the number of market-size clams (rule 1), the percentage of simulations where fewer $10^{\prime}$ squares were fished was much higher. This result suggests that these $10^{\prime}$ squares retain high catch rates longer under closure location rule 1 . When the closure location is based on rule 1 , transit distance was increased in substantially fewer simulations in comparison with closure location based on closure location rule 2 or present-day management. A decrease in distance traveled in a comparison of closure location rules 1 and 2 suggests that when importance is placed on the ratio of the number of small clams to the number of market-size clams, even though the 10' squares closed may be near home ports, once open they provide improved catch rates more often than if the location of the closed $10^{\prime}$ square was selected on the basis of abundance of small clams alone. This outcome is consistent with the more persistent targeting of these $10^{\prime}$ squares under closure location rule 1.

The average percent increase in the number of clams per bushel-a metric directly related to the size of landed clams-is essentially equal for both closure location rules. Because some of the performance metrics (e.g., number of clams per bushel) showed little difference between the 2 closure rules, a third option of combining the 2 rules might offer additional benefits for the commercial fishery. However, on the basis of the percentage of simulations that indicated improvement of the stock and the margins of increase, the 5 -year closure duration under closure location rule 1 , which relies on the proportion of small clams to identify a $10^{\prime}$ square to close, offers the most benefit for the stock and therefore is identified as the preferred option. Of greatest importance is the increase in whole-stock density that occurs while landings are retained near levels of the present day. In addition, based on the percentage of simulations that indicate additional economic opportunities offered to the commercial fishery, the 5-year closure duration under closure location rule 1 offers the most benefit to the stock and thus again is identified as the preferred option.

\section{Influence of incidental mortality}

Little information exists about the incidental mortality of clams encountered by the dredge but that remain on the seafloor. NEFSC 2 assumes $12 \%$ incidental mortality, but this assumption is based on very little data and primarily on the outcome for market-size clams (Meyer et al., 1981), few of which 
remain uncaught with modern high-performance hydraulic dredges (Hennen et al., 2012; NEFSC ${ }^{2}$ ). The fate of small clams is effectively unknown. Therefore, we investigated the effect of area management under the assumption of $0 \%$ and $20 \%$ incidental mortality. Pairwise comparisons of the present-day management simulation under the assumption of increased incidental mortality with simulations implementing area management options, also with increased incidental mortality, produced performance metrics that were then compared with the performance metrics with $0 \%$ mortality. Additional mortality enhanced the positive effect of area management in most situations under closure location rule 1 . The percentage of simulations with enhanced performance metrics under area management was greater with increased incidental mortality. Also, the average percent increase across all metrics was enhanced. In most simulations with the use of closure location rule 2 , increased incidental mortality had little effect on the percentage of simulations with improved performance metrics. The most notable difference in the percentage of simulations with improved performance metrics in comparisons of the 2 levels of incidental mortality is seen in the total distance traveled. A larger percentage of simulations with increased distance traveled is seen with $0 \%$ incidental mortality in contrast with simulations with $20 \%$ incidental mortality. A large effect of incidental mortality with the use of closure location rule 1 and a small effect with closure location rule 2 suggests that a combination of the 2 closure location rules could offer some clarity for determining the real effect of increased incidental mortality.

The enhancement of the effect of area management at increased levels of incidental mortality can be attributed to the protection of clams in closed areas. The effect of area management is enhanced because 10' squares with high clam abundances (regardless of the closure rule) are protected, and thus fewer are removed from the stock as a result of incidental mortality. When incidental mortality is increased from $0 \%$ to $20 \%$, mortality is increased in areas that are fished; however, in the closed areas, this mortality is not occurring and these regions have the highest number of clams that would be subject to this source of mortality.

\section{Preferred management options}

The importance of the presence and abundance of small clams becomes apparent upon examining the performance metrics that suggest improvement over present-day management. Of the 2 closure location rules, the rule that places importance on a population dominated by small clams (rule 1) produces a greater increase in simulated stock abundance and LPUE over time in comparison with a a location closed on the basis of the density of small clams (rule 2). An increase in the percentage of simulations where fewer $10^{\prime}$ squares are fished occurs because the closed 10' squares produce higher catch rates once open than the $10^{\prime}$ squares that are not closed. An increase in the distance traveled during fishing trips is also seen, some of which results from closed $10^{\prime}$ squares being close to home ports and some of which stems from the favorable (i.e., higher) LPUEs in recently opened $10^{\prime}$ squares farther from port. No obvious difference is seen between the 2 closure location rules for the size of landed clams (i.e., the number of clams per bushel). This difference between area management and present-day management in the size of clams landed is nonetheless of great importance because the lower fishing mortality rate increases survivorship of large clams and contributes to the increase in whole-stock density routinely observed in area management simulations, directly and through an increase in spawning stock biomass.

Simulations indicate that the 5-year closure duration derives the largest benefits for the stock and also the commercial fishing industry. Although average percent increases in stock density and LPUE are greater when closure duration is longer, the percentage of simulations showing improvement over present-day management is greatest with the 5-year closure duration. Based on the overall improvements in performance metrics seen with closure location rule 1 and the 5-year closure duration simulations, the preferred option that simultaneously offers additional opportunities for growth of the stock and improvements to the commercial fishery is to close areas specified by closure location rule 1 for 5 years. Future research into area management options should include an investigation of an intermediate closure rule or a combination of closure rules. Nonetheless, the results of these analyses strongly suggest that both the Atlantic surfclam stock and fishery would experience a positive change by the inclusion of an area management program in the MAB region.

\section{Acknowledgments}

This research was supported by the National Science Foundation (NSF) Science Center for Marine Fisheries (SCeMFiS) under NSF award 1266057 and through membership fees provided by the SCeMFiS Industry Advisory Board. This article is based, in part, on a thesis submitted by the senior author for fulfillment of the Master of Science degree at The University of Southern Mississippi. The authors thank the SCeMFiS member organizations for providing detailed information on vessel characteristics for all vessels targeting Atlantic surfclams, which allowed realistic simulations of the industry to be performed.

\section{Literature cited}

Alexander, R. R., and G. P. Dietl.

2001. Shell repair frequencies in New Jersey bivalves: a recent baseline for tests of escalation with tertiary, midAtlantic congeners. Palaios 16:354-371. Article 
Bastardie, F., M. Vinther, J. R. Nielsen, C. Ulrich, and M. S. Paulsen.

2010. Stock-based vs. fleet-based evaluation of the multiannual management plan for the cod stocks in the Baltic Sea. Fish. Res. 101:188-202. Article

Baudron, A., C. Ulrich, J. R. Nielsen, and J. Boje.

2010. Comparative evaluation of a mixed-fisheries effortmanagement system based on the Faroe Islands example. ICES J. Mar. Sci. 67:1036-1050. Article

Bloomfield, H. J., C. J. Sweeting, A. C. Mill, S. M. Stead, and N. V. C. Polunin.

2012. No-trawl area impacts: perceptions, compliance and fish abundances. Environ. Conserv. 39:237-247. Article

Bockstael, N. E., and J. J. Opaluch.

1983. Discrete modelling of supply response under uncertainty: the case of the fishery. J. Environ. Econ. Manage. 10:125-137. Article

Butterworth, D. S., and A. E. Punt.

1999. Experiences in the evaluation and implementation of management procedures. ICES J. Mar. Sci. 56:985-998. Article

Butterworth, D. S., K. L. Cochrane, and J. A. A. De Oliveira.

1997. Management procedures: a better way to manage fisheries? The South African experience. In Global trends: fisheries management; (E. K. Pikitch, D. D. Huppert, and M. P. Sissenwine, eds.), p. 83-90. Am. Fish. Soc., Bethesda, MD.

Cargnelli, L. M., S. J. Griesbach, D. B. Packer, and E. Weissberger.

1999. Essential fish habitat source document: Atlantic surfclam, Spisula solidissima, life history and habitat characteristics. NOAA Tech. Memo. NMFS-NE-142, 13 p.

Conover, W. J.

1980. Practical nonparametric statistics, 2 ed., 493 p. John Wiley and Sons Inc., New York.

Cooley, S. R., J. E. Rheuban, D. R. Hart, V. Luu, D. M. Glover, J. A. Hare, and S. C. Doney.

2015. An integrated assessment model for helping the United States sea scallop (Placopecten magellanicus) fishery plan ahead for ocean acidification and warming. PLoS ONE 10(5):e0124145. Article

Córdova-Lepe, F., R. Del Valle, and G. Robeldo.

2012. A pulse fishery model with closures as function of the catch: conditions for sustainability. Math. Biosci. 239:169-177. Article

Dorn, M. W.

2001. Fishing behavior of factory trawlers: a hierarchical model of information processing and decision-making. ICES J. Mar. Sci. 58:238-252. Article

Feely, R. A., S. C. Doney, and S. R. Cooley.

2009. Ocean acidification: present conditions and future changes in a high- $\mathrm{CO}_{2}$ world. Oceanography 22:36-47. Article

Francis, R. I. I. C., and R. Shotton.

1997. "Risk" in fisheries management: a review. Can. J. Fish. Aquat. Sci. 54:1699-1715. Article

Gilkinson, K. D., D. C. Gordon Jr., K. G. MacIsaac, D. L. McKeown, E. L. R. Kenchington, C. Bourbonnais, and W. P. Vass.

2005. Immediate impacts and recovery trajectories of macrofaunal communities following hydraulic clam dredging on Banquereau, eastern Canada. ICES J. Mar. Sci. 62:925-947. Article
Gillis, D. M., R. M. Peterman, and E. K. Pikitch.

1995. Implications of trip regulations for high-grading; a model of the behavior of fishermen. Can. J. Fish. Aquat. Sci. 52:402-415. Article

Goldberg, R., and R. L. Walker.

1990. Cage culture of yearling surf clams, Spisula solidissima (Dillwyn, 1817), in coastal Georgia. J. Shellfish Res. 9:187-193.

Hennen, D. R., L. D. Jacobson, and J. Tang.

2012. Accuracy of the Patch model used to estimate density and capture efficiency in depletion experiments for sessile invertebrates and fish. ICES J. Mar. Sci. 69:240-249. Article

Hilborn, R.

1992. Current and future trends in fisheries stock assessment and management. S. Afr. J. Mar. Sci. 12:975-988. Article

2003. The state of the art in stock assessment: where we are and where we are going. Sci. Mar. 67:15-20. Article

Hofmann, E. E., E. N. Powell, J. M. Klinck, D. M. Munroe, R.

Mann, D. B. Haidvogel, D. A. Narváez, X. Zhang, and K. M.

Kuykendall.

In press. Factors affecting distribution of the Atlantic surfclam (Spisula solidissima), a continental shelf biomass dominant, during a period of climate change. J. Shellfish Res.

Holland, D. S., and J. G. Sutinen.

2000. Location choice in New England trawl fisheries: old habits die hard. Land Econ. 76:133-149.

Hutton, T., S. Mardle, S. Pascoe, and R. A. Clark.

2004. Modelling fishing location choice within mixed fisheries: English North Sea beam trawlers in 2000 and 2001. ICES J. Mar. Sci. 61:1443-1452. Article

Kim, Y., and E. N. Powell.

2004. Surfclam histopathology survey along the Delmarva mortality line. J. Shellfish Res. 23:429-441.

Link, P. M., U. A. Schneider, and R. S. J. Tol.

2011. Economic impacts of changes in fish population dynamics: the role of the fishermen's harvesting strategies. Environ. Model. Assess. 16:413-429. Article

Loesch, J. G., and J. W. Ropes.

1977. Assessment of the surfclam stocks in near shore waters along the Delmarva Peninsula and in the fishery south of Cape Henry. Proc. Natl. Shellfish. Assoc. 67:29-34.

Mackinson, S., U. R. Sumaila, and T. J. Pitcher.

1997. Bioeconomics and catchability: fish and fishers behaviour during stock collapse. Fish. Res. 31:11-17. Article

Mahévas, S., and D. Pelletier.

2004. ISIS-Fish, a generic and spatially explicit simulation tool for evaluating the impact of management measures on fisheries dynamics. Ecol. Model. 171:65-84. Article

Marzec, R. J., Y. Kim, and E. N. Powell.

2010. Geographical trends in weight and condition index of surfclams (Spisula solidissima) in the mid-Atlantic Bight. J. Shellfish Res. 29:117-128. Article

McAllister, M. K., and G. P. Kirkwood.

1998. Bayesian stock assessment: a review and example application using the logistic model. ICES J. Mar. Sci. 55:1031-1060. Article

McCay, B. J., C. F. Creed, A. C. Finlayson, R. Apostle, and K. Mikalsen.

1995. Individual transferrable quotas (ITQs) in Canadian and US fisheries. Ocean Coast. Manage. 28:85-115. Article 
Meyer, T. L., R. A. Cooper, and K. J. Pecci.

1981. The performance and environmental effects of a hydraulic clam dredge. Mar. Fish. Rev. 43(9):14-22.

Miller, T. J., J. A. Blair, T. F. Ihde, R. M. Jones, D. H. Secor, and M. J. Wilberg.

2010. FishSmart: an innovative role for science in stakeholder-centered approaches to fisheries management. Fisheries 35:424-433. Article

Millischer, L., and D. Gascuel.

2006. Information transfer, behavior of vessels and fishing efficiency: an individual-based simulation approach. Aquat. Living Resour. 19:1-13. Article

Monroy, C., S. Salas, and J. Bello-Pineda.

2010. Dynamics of fishing gear and spatial allocation of fishing effort in a multispecies fleet. N. Am. J. Fish. Manage. 30:1187-1202. Article

Moschino, V., M. Deppieri, and M. G. Marin.

2003. Evaluation of shell damage to the clam Chlamelea gallina captured by hydraulic dredging in the northern Adriatic Sea. ICES J. Mar. Sci. 60:393-401. Article

Munroe, D. M., E. N. Powell, R. Mann, J. M. Klinck, and E. E. Hofmann.

2013. Underestimation of primary productivity on continental shelves: evidence from maximum size of extant surfclam populations. Fish. Oceanogr. 22:220-233. Article

Munroe, D. M., D. A. Narváez, D. Hennen,' L. Jacobson, R. Mann, E. E. Hofmann, E. N. Powell, and J. M. Klinck.

2016. Fishing and bottom water temperature as drivers of change in maximum shell length in Atlantic surfclams (Spisula solidissima). Estuar. Coast. Shelf Sci. 170:112-122. Article

NOAA (National Oceanic and Atmospheric Administration).

2012. Magnuson-Stevens Fishery Conservation and Management Act provisions; fisheries of the northeastern United States; Atlantic surfclam and ocean quahog fishery. Fed. Reg. 77(244):75057-75064.

Narváez, D. A., D. M. Munroe, E. E. Hofmann, J. M. Klinck, E. N. Powell, R. Mann, and E. Curchitser.

2015. Long-term dynamics in Atlantic surfclam (Spisula solidissima) populations: the role of bottom water temperature. J. Mar. Syst. 141:136-148. Article

Powell, E. N., K. A. Ashton-Alcox, J. N. Kraeuter, S. E. Ford, and D. Bushek.

2008. Long-term trends in oyster population dynamics in Delaware Bay: regime shifts and response to disease. J. Shellfish Res. 27:729-755. Article

Powell, E. N., J. M. Klinck, D. M. Munroe, E. E. Hofmann, P. Moreno, and R. Mann.

2015. The value of captains' behavioral choices in the success of the surfclam (Spisula solidissima) fishery on the U.S. Mid-Atlantic coast: a model evaluation. J. Northwest Atl. Fish. Sci. 47:1-27.

Powell, E. N., J. M. Klinck, E. E. Hofmann, P. Moreno, K. M. Kuykendall, D.M. Munroe, and R. Mann.

2016. Captains' response to a declining stock as anticipated in the surfclam (Spisula solidissima) fishery on the U.S. Mid-Atlantic coast by model evaluation. Ocean Coast. Manage. 134:52-68. Article

Prior, D. J., A. M. Schneiderman, and S. I. Greene.

1979. Size-dependent variation in the evasive behaviour of the bivalve mollusc Spisula solidissima. J. Exp. Biol. 78:59-75.
Punt, A. E., and R. Hilborn.

1997. Fisheries stock assessment and decision analysis: the Bayesian approach. Rev. Fish Biol. Fish. 7:35-63. Article

Punt, A. E., F. Trinnie, T. I. Walker, E. McGarvey, J. Feenstra, A. Linnane, and K. Hartmann.

2013. The performance of a management procedure for rock lobsters, Jasus edwardsii, off western Victoria, Australia in the face of non-stationary dynamics. Fish. Res. 137:116-128. Article

Punt, A. E., T. A'mar, N. A. Bond, D. S. Butterworth, C. L. de Moor, J. A. A. De Oliveira, M. A. Haltuch, A. B. Hollowed, and C. Szuwalski.

2014. Fisheries management under climate and environmental uncertainty: control rules and performance simulation. ICES J. Mar. Sci. 71:2208-2220. Article

Ropes, J. W., and A. S. Merrill.

1973. To what extent do surf clams move. Nautilus 87:19-21.

Scavia, D., J. C. Field, D. F. Boesch, R. W. Buddemeier, V. Burkett, D. R. Cayan, M. Fogarty, M. A. Harwell, R. W. Howarth, C. Mason, et al.

2002. Climate change impacts on U.S. coastal and marine ecosystems. Estuaries 25:149-164. Article

Smith, A. D. M.

1994. Management strategy evaluation-the light on the hill. In Population dynamics for fisheries management. Australian Society for Fish Biology workshop proceedings; Perth, Australia, 24-25 August 1993 (D. A. Hancock, ed.), p. 249-253. Australian Society for Fish Biology, North Beach, Australia.

Spillman, C. M., D. P. Hamilton, and J. Imberger.

2009. Management strategies to optimise sustainable clam (Tapes philippinarum) harvests in Barbamarco Lagoon, Italy. Estuar. Coast. Shelf Sci. 81:267-278. Article

van Putten, I. E., S. Kulmala, O. Thébaud, N. Dowling, K. G. Hamon, T. Hutton, and S. Pascoe.

2012. Theories and behavioural drivers underlying fleet dynamics models. Fish Fish. 13:216-235. Article

Vasconcelos, P., A. Morgado-André, D. Morgado-André, and M. B. Gaspar.

2011. Shell strength and fishing damage to the smooth clam (Callista chione): simulating impacts caused by bivalve dredging. ICES J. Mar. Sci. 68:32-42. Article

Walters, C.

2000. Impacts of dispersal, ecological interactions, and fishing effort dynamics on efficacy of marine protected areas: how large should protected areas be? Bull. Mar. Sci. 66:745-757.

Weinberg, J. R.

1998. Density-dependent growth in the Atlantic surfclam, Spisula solidissima, off the coast of the Delmarva Peninsula, USA. Mar. Biol. 130:621-630. Article

1999. Age-structure, recruitment, and adult mortality in populations of the Atlantic surfclam, Spisula solidissima, from 1978 to 1997. Mar. Biol. 134:113-125. Article

2005. Bathymetric shift in the distribution of Atlantic surfclams: response to warmer ocean temperature. ICES J. Mar. Sci. 62:1444-1453. Article

Weinberg, J. R., T. G. Dahlgren, and K. M. Halanych.

2002. Influence of rising sea temperature on commercial bivalve species of the U.S. Atlantic coast. Am. Fish. Soc. Symp. 32:131-140. 
Witbaard, R., and R. Klein.

1994. Long-term trends on the effects of the southern North Sea beamtrawl fishery on the bivalve mollusc Arctica islandica L. (Mollusca, Bivalvia). ICES J. Mar. Sci. 51:99-105. Article

Zhang, X., D. Haidvogel, D. Munroe, E. N. Powell, J. Klinck, R. Mann, and F. S. Castruccio.

2015. Modeling larval connectivity of the Atlantic surf- clams within the Middle Atlantic Bight: model development, larval dispersal and metapopulation connectivity. Estuar. Coast. Shelf Sci. 153:38-53. Article

Zhang, X., D. Munroe, D. Haidvogel, and E. N. Powell. 2016. Atlantic surfclam connectivity within the Middle Atlantic Bight: mechanisms underlying variation in larval transport and settlement. Estuar. Coast. Shelf Sci. 173:65-78. Article 